\title{
Gut microbial metabolites in depression: understanding the biochemical mechanisms
}

\author{
Giorgia Caspani ${ }^{1}$, Sidney Kennedy ${ }^{2-5}$, Jane A. Foster ${ }^{6, *}$ and Jonathan Swann ${ }^{1}$ \\ ${ }^{1}$ Computational Systems Medicine, Department of Surgery and Cancer, Imperial College London, UK. \\ ${ }^{2}$ Centre for Mental Health and Krembil Research Centre, University Health Network, University of Toronto, Toronto, ON, CA. \\ ${ }^{3}$ Mental Health Services, St. Michael's Hospital, University of Toronto, Toronto, ON, CA \\ ${ }^{4}$ Department of Psychiatry, University of Toronto, Toronto, ON, CA. \\ ${ }^{5}$ Keenan Research Centre for Biomedical Science, Li Ka Shing Knowledge Institute, St. Michael's Hospital, Toronto, ON, CA. \\ ${ }^{6}$ Department of Psychiatry \& Behavioral Neurosciences, McMaster University, Hamilton, Ontario, Canada. \\ * Corresponding Author: \\ Jane Foster, Department of Psychiatry \& Behavioral Neurosciences, McMaster University, Ontario, Canada; E-mail: jfoster@mcmaster.ca
}

\begin{abstract}
Gastrointestinal and central function are intrinsically connected by the gut microbiota, an ecosystem that has coevolved with the host to expand its biotransformational capabilities and interact with host physiological processes by means of its metabolic products. Abnormalities in this microbiota-gut-brain axis have emerged as a key component in the pathophysiology of depression, leading to more research attempting to understand the neuroactive potential of the products of gut microbial metabolism. This review explores the potential for the gut microbiota to contribute to depression and focuses on the role that microbiallyderived molecules - neurotransmitters, short-chain fatty acids, indoles, bile acids, choline metabolites, lactate and vitamins play in the context of emotional behavior. The future of gut-brain axis research lies is moving away from association, towards the mechanisms underlying the relationship between the gut bacteria and depressive behavior. We propose that direct and indirect mechanisms exist through which gut microbial metabolites affect depressive behavior: these include (i) direct stimulation of central receptors, (ii) peripheral stimulation of neural, endocrine, and immune mediators, and (iii) epigenetic regulation of histone acetylation and DNA methylation. Elucidating these mechanisms is essential to expand our understanding of the etiology of depression, and to develop new strategies to harness the beneficial psychotropic effects of these molecules. Overall, the review highlights the potential for dietary interventions to represent such novel therapeutic strategies for major depressive disorder.
\end{abstract}

doi: $10.15698 / \mathrm{mic} 2019.10 .693$

Received originally: 26.05.2019;

in revised form: 12.09.2019,

Accepted 13.09.2019,

Published 27.09.2019.

Keywords: microbiome, indole, tryptophan, bile acids, lactate, vitamins, mental health.
Abbreviations:

3-HK - 3-hydroxykynurenine, 5-HIAA - 5-hydroxyindole acetic acid, 5-HT - 5-hydroxytryptamine, AhR - aryl hydrocarbon receptor, BBB - blood-brain barrier, BDNFbrain-derived neurotrophic factor, CNS - central nervous system, CUMS - chronic unpredictable mild stress, FXR - farnesoid $X$ receptor, GABA - $\gamma$-aminobutyric acid, GI - gastrointestinal, HDAC - histone deacetylase, HPA - hypothalamic pituitary adrenal, IAId - Indole-3aldehyde, IDO - Indoleamine-2,3-dioxygenase, IFN - interferon, IL - interleukin, IPA - indole-3-propionic acid, KYNA - kynurenic acid, LPS - lipopolysaccharide, MDD - major depressive disorder, NMDA - N-methyl-Daspartate, PXR - pregnane $X$ receptor, SAM - S adenosylmethionine, SCFA - short-chain fatty acid, TDO - tryptophan-2,3-dioxygenase, TET - ten-eleven translocation, TGR5 - Takeda G protein-coupled receptor 5, TMA - trimethylamine, TMAO - trimethylamine- $N$ oxide, TNF- $\alpha$ - tumor necrosis factor- $\alpha$, TPH - tryptophan hydroxylase, TUDCA - tauroursodeoxycholic acid, VDR - vitamin D receptor.

\section{THE GUT MICROBIOME CONTRIBUTES TO DEPRESSIVE BEHAVIOR}

With an estimated three to four million different genes in the collective genomes of the gut microbiota [1] there is approximately 100 to 150 times more genetic information in the human microbiome than the human genome. Many of these genes encode proteins that perform metabolic functions and produce metabolites exclusive to the microbiome. The host encounters these metabolites in the gut, where they can exert local effects in the gastrointestinal
(GI) environment or at the gut wall. Alternatively, these microbial metabolites can be absorbed, enter the systemic circulation and reach distant organs, including the brain. At these host sites, microbial metabolites can serve as ligands for host receptors with downstream effects on host gene expression and function. In addition, these microbial metabolites can integrate into host metabolic pathways altering their activity (Figure 1).

Colonization of the human gut by the microbiota is an evolutionary-driven process that impacts host physiology, 


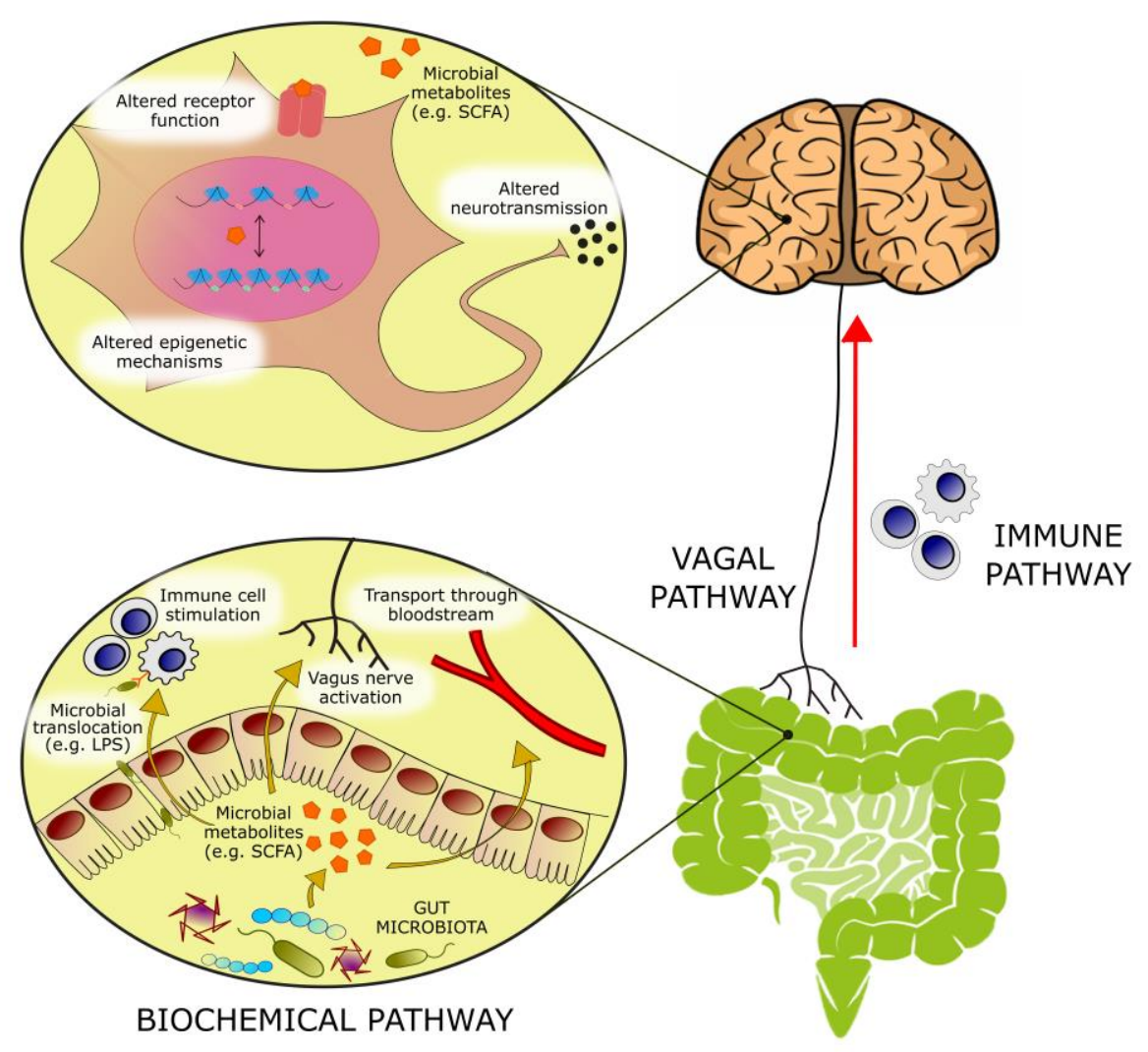

FIGURE 1: Bioactive molecules originating from microbial metabolism are thought to modulate emotional behavior through several mechanisms:

(1) Activation of afferent vagal nerve fibers.

(2) Stimulation of the mucosal immune system or of circulatory immune cells after translocation from the gut into the circulation.

(3) Absorption into the bloodstream, and biochemical interaction with a number of distal organs. In the brain, such metabolites may be able to activate receptors on neurons or glia, modulate neuronal excitability, and change expression patterns by means of epigenetic mechanisms. for example, by priming the immune system and aiding the breakdown of otherwise indigestible fibers, and also by driving brain development and shaping behavior [2]. It is now well established that a bidirectional communication network exists between the gut and the brain, termed the gut-brain axis [3], of which the microbiota and its metabolic output are a major component. Colonization of the gut by the microbiota and central nervous system (CNS) development have extensively overlapping critical developmental windows. As a result, early-life perturbations in the maturation of the microbiota can result in deficits in neurogenesis, axonal and dendritic growth and synaptogenesis, which can negatively impact on later mental health [4]. Indeed, compared to specific pathogen-free and conventional mice, germ-free mice exhibited an exaggerated hypothalamic pituitary adrenal (HPA) axis response to restraint stress, characterized by elevated plasma adrenocorticotropic hormone (ACTH) and corticosterone as well as reduced cortical and hippocampal expression of brainderived neurotrophic factor (BDNF) [5]. Fecal inoculation from specific pathogen-free donor mice reversed these stress-associated physiological alterations only when administered at early developmental stages. This suggests that early-life colonization by the gut microbiota is essential for the normal development of the HPA axis and of the neuroendocrine response to stress [5] and supports the notion that a limited, early critical window exists in which gut microbial stimulation shapes normal brain development [2].

Major depressive disorder (MDD) has become the leading cause of disability globally and is associated with death and suicide, more often than any other mental or physical disorder. The symptomatology of MDD includes prolonged feelings of low mood, worthlessness or guilt, anhedonia, sleep and appetite disturbances, fatigue, slowed movements and speech, and suicidal thoughts [6]. In addition to CNS abnormalities, patients with depression also exhibit alterations in metabolic, immune and endocrine systems. There is growing evidence associating the gut microbiota in the pathophysiology of depression. Several taxonomic association studies in humans have observed differences in the fecal microbiota composition of MDD patients compared to healthy subjects [7-10]. These studies identified variation in the phyla Bacteroidetes, Proteobacteria, Actinobacteria and Firmicutes, and in the genera Enterobacteriaceae, Alistipes, Faecalibacterium, Bifidobacterium and Blautia, although contradicting results were found regarding the direction of the associations detected between disease and bacterial taxa. Valles-Colomer and colleagues [11] used a module-based analytical approach of fecal metagenomes to link microbiota neuroactive capacity with depressive symptoms. This study showed a positive association between quality of life indicators and the genera Faecalibacterium and Coprococcus, as well as a negative association between the abundance of Coprococcus spp. 
and Dialister with depression after controlling for antidepressant use. Psychological stress can change the composition of the gut microbiota [12], and in turn, microbiota abnormalities can influence emotional behavior [13]. Germ-free rodent studies have begun to interrogate the causative role of microbiome abnormalities in the etiology of depression. Alongside the appearance of anhedonia and anxiety-like behavior, the oral gavage of fecal microbiota from MDD patients to antibiotic-treated rats induced decreased gut microbiota richness and diversity and elevated plasma kynurenine and kynurenine/tryptophan ratio [14], highlighting the potential to transfer depressive-like behavioral and physiological traits via the microbiota. Tryptophan metabolism along the serotonin (also known as 5hydroxytryptamine or 5-HT), kynurenine and indole pathways can be influenced by the gut microbiota. The bacterial enzyme tryptophanase is responsible for the conversion of tryptophan into indole, which can give rise to a range of neuroactive signaling molecules. Additionally, tryptophan can be metabolized into 5-HT, via aromatic amino acid decarboxylase (AAAD) activity, or kynurenine by the enzymes tryptophan-2,3-dioxygenase (TDO) or the ubiquitous indoleamine-2,3-dioxygenase (IDO). Lipopolysaccharides (LPS), an inflammatory cell wall component from Gram negative bacteria, can induce the expression of IDO, increasing the conversion of tryptophan to kynurenine (reflected in the kynurenine:tryptophan ratio). The reduction in Firmicutes and the subsequent decrease in short-chain fatty acid synthesis observed in MDD patients has been linked to increased inflammation [15], and cytokines are also known to promote tryptophan utilization for kynurenine synthesis via IDO activity. This pathway gives rise to the neurotoxic metabolite quinolinic acid, and reduces central serotonergic availability [16]. Much of the mechanistic evidence of the involvement of the gut microbiota in depression comes from research on germ-free or on microbiota-depleted animals. Germ-free rodent models show substantial behavioral and molecular abnormalities (Table 1), represented by reduced anxiety and changes in central levels of several neurotransmitters, both of which could be rescued following colonization with a conventional microbiota early in life $[17,18]$. Depletion of the gut microbiota by antibiotic administration was also found to induce depressive-like behaviors in adult rats, as well as altered central 5-HT availability and other depressionrelated physiological changes [19].

\section{PATHWAYS OF MICROBIOTA-GUT-BRAIN- COMMUNICATION}

The gut microbiota and its metabolic products can affect central physiological and pathological processes through several proposed mechanisms. Neural communication between the gut and the brain is mainly mediated by intestinal afferent fibers of the vagus nerve. Vagal stimulation by the gut microbiota or its metabolites is relayed to the nucleus tractus solitarius, and then transmitted to the thalamus, hypothalamus, locus coeruleus, amygdala and periaqueductal grey [3]. Electrical stimulation of the vagus nerve by the gut microbiota can alter the concentrations of neurotransmitters like 5 - $\mathrm{HT}, \mathrm{v}$-aminobutyric acid (GABA) and glutamate in the brain of both rodents and humans [20]. Additionally, rodent studies have shown that the anxiety and depressive phenotype that is normally induced by an immune challenge can be prevented by vagotomy [21, 22], supporting the role played by the vagus nerve in stress reactivity and emotional regulation.

The immune system represents a major component of gut-to-brain communication. While central immune cells and low levels of inflammatory mediators exert a variety of physiological roles in the brain (ranging from sleep to memory formation), sustained neuroinflammation has deleterious effects on brain function and has been associated with a variety of neuropsychiatric disorders [23]. The gut microbiota has important roles in shaping immune function throughout life. In early life, it directs normal development of central immune cells, like microglia and astrocytes [24]; in adulthood, it sets a chronic physiological state of low-grade inflammation [25], as the bacterial antigens present in the intestinal tract stimulate cytokine release by intestinal macrophages and T cells [26]. Peptidoglycans derived from bacterial cell walls have been measured in the brain, where they activate central patternrecognition receptors to stimulate the innate immune system and alter behavior [27]. These observations are consistent with a role for immune molecules in the CNS independent of infection or immune stimulation, but actually a component of normal healthy brain function.

The gut microbiota is also central to brain function in the context of an immune challenge. LPS can trigger the release of the cytokine IL-18 [28]. Parenteral administration of LPS to healthy individuals induced immune system activation accompanied with mild depressive and cognitive symptoms [29]. Significantly, LPS translocation into the brain is suggested to be under the control of propionate, a gut microbial metabolite that modulates blood-brain barrier (BBB) permeability [30]. Pro-inflammatory cytokines in the $\mathrm{Gl}$ tract can also modulate central stress circuitry by stimulating the vagus nerve and activating the HPA axis [31]. Stress and dietary patterns such as the Western diet can contribute to neuroinflammation by increasing the permeability of the intestinal wall, a pathological state referred to as "leaky gut". This allows the translocation of bacteria and LPS from the intestinal lumen into the bloodstream and the CNS [25].

Finally, direct biochemical signaling can take place by means of bioactive molecules of bacterial origin. Extensive studies in germ-free and antibiotic-treated rodents have highlighted the diverse biochemical output of the microbiome. This diversity is a product of the chemically heterogeneous substrate entering the gut from both the diet and host secretions as well as from the expansive metabolic repertoire of the microbiome [32]. Metabolites produced in the gut by the bacterial fermentation of dietary components can be absorbed in the bloodstream and interact with enzymes and receptors expressed by the host, contributing to both physiological and pathological processes in the host [33]. To date, evidence suggests that microbio- 
TABLE 1. Studies investigating the effect of a lack of microbiota on neurotransmitter systems.

\begin{tabular}{|c|c|c|c|c|}
\hline Model & Species or strain & $\begin{array}{c}\text { Behavioral out- } \\
\text { comes }\end{array}$ & Molecular mechanisms & Reference \\
\hline GF & $\begin{array}{l}\text { Adult male BALB/c } \\
\text { mice (7-9 weeks) }\end{array}$ & - & $\begin{array}{l}\text { Biologically inactive and conjugated form of colonic } \\
\text { norepinephrine and dopamine in GF mice (compared } \\
\text { to the biologically active, free form in conventional } \\
\text { mice); reduced intestinal norepinephrine and dopa- } \\
\text { mine rescued by microbiota recolonisation }\end{array}$ & {$[45]$} \\
\hline GF & $\begin{array}{l}\text { Male Swiss Web- } \\
\text { ster mice }(8-10 \\
\text { weeks) }\end{array}$ & - & $\begin{array}{l}\text { altered blood concentrations of indole derivatives } \\
\text { (including } \uparrow \text { tryptophan and } \downarrow 5-\mathrm{HT} \text { ), phenyl deriva- } \\
\text { tives (including } \uparrow \text { tyrosine) and other metabolites in } \\
\text { GF compared to conventional mice }\end{array}$ & {$[32]$} \\
\hline GF & $\begin{array}{c}\text { Male BALB/c mice } \\
\text { (7 weeks) }\end{array}$ & - & $\begin{array}{l}\text { Altered cerebral metabolome (including } \downarrow \text { trypto- } \\
\text { phan and tyrosine, but } \uparrow \text { dopamine and } N \text { - } \\
\text { acetylaspartatic acid) of germ-free mice compared to } \\
\text { Ex-GF mice, which were inoculated with suspension } \\
\text { of feces from SPF mice; reduced GABA in faeces and } \\
\text { blood (but not in brain) rescued by microbiota recol- } \\
\text { onisation }\end{array}$ & {$[46]$} \\
\hline GF & $\begin{array}{l}\text { Male and female } \\
\text { Swiss Webster } \\
\text { mice }\end{array}$ & $\begin{array}{l}\text { 个 anxiety pheno- } \\
\text { type normalised by } \\
\text { conventionalisation }\end{array}$ & $\begin{array}{c}\downarrow \text { immune response and } \uparrow \text { HPA axis reactivity in GF } \\
\text { mice; } \downarrow \text { BDNF expression in hippocampus; } \uparrow \text { hippo- } \\
\text { campal 5-HT and 5-HIAA in males only; } \uparrow \text { plasma } \\
\text { tryptophan availability and } \downarrow \text { kynurenine:tryptophan } \\
\text { ratio in males (restored by colonisation); } \uparrow \text { hippo- } \\
\text { campal 5-HT and 5-HIAA not normalised by conven- } \\
\text { tionalisation }\end{array}$ & {$[49]$} \\
\hline GF & $\begin{array}{c}\text { Male mice (8-10 } \\
\text { week) }\end{array}$ & $\begin{array}{c}\downarrow \text { anxiety-like be- } \\
\text { havior }\end{array}$ & $\begin{array}{l}\text { 个norepinephrine, Dopamine, and 5-HT turnover in } \\
\text { the Striatum; Altered Expression of Synaptic Plastici- } \\
\text { ty-Related Genes; Colonization of GF Mice Reduces } \\
\text { Protein Expression of Synaptophysin and PSD-95 in } \\
\text { Striatum }\end{array}$ & {$[2]$} \\
\hline GF & C57BI/6J mice & - & $\begin{array}{l}\downarrow \text { circulatory and faecal (colonic ECS) 5-HT in GF } \\
\text { compared to SPF mice; colonisation of GF mice with } \\
\text { SPF microbiota restores serotonergic abnormalities, } \\
\text { elevates TPH1 expression and decreases SLC6A4 ex- } \\
\text { pression. }\end{array}$ & {$[48]$} \\
\hline GF & BALB/c mice & - & $\begin{array}{c}\text { Altered intestinal concentration of several metabo- } \\
\text { lites (including } \downarrow \text { GABA in GF compared to colonised } \\
\text { mice) }\end{array}$ & {$[53]$} \\
\hline GF & $\begin{array}{l}\text { Male Swiss Web- } \\
\text { ster mice }(12-14 \\
\quad \text { weeks) }\end{array}$ & - & $\begin{array}{c}\text { Altered levels of microbial metabolites in serum of GF } \\
\text { compared to conventional mice, including } \downarrow \text { serum } \\
\text { concentrations of dopamine and tyramine and of } \\
\text { trans - } \\
\text { 2-aminomethylcyclopropanecarboxylic acid, a cyclo- } \\
\text { propane analog of GABA }\end{array}$ & {$[52]$} \\
\hline
\end{tabular}

5-HIAA: 5-Hydroxyindoleacetic Acid; 5-HT: 5-Hydroxytryptamine; BDNF: Brain-Derived Neurotrophic Factor; GABA: GammaAminobutyric Acid; GF: Germ-Free; HPA: Hypothalamic-Pituitary-Adrenal; PSD-95: Postsynaptic Density Protein 95; SLC6A4: Serotonin Transporter; SPF: Specific Pathogen Free; TPH-1: Tryptophan Hydroxylase 1.

ta-derived acetate can act remotely to influence neural function [34]. Neurotransmitters, short-chain fatty acids (SCFAs), bile acids, choline metabolites, lactate and vitamins are products of gut microbial metabolism that can directly or indirectly influence central processes and, when dysregulated, contribute to neuropathology [25]. This review will focus on the potential of these metabolite classes to alter biochemical processes underlying gut-to-brain communication, and describe the role played by these microbial metabolites in the pathophysiology of depression.
NEUROACTIVE MICROBIAL METABOLITES AND THEIR ROLE IN DEPRESSION

\section{Neurotransmitters}

The majority of central neurotransmitters are also present in the Gl tract, where they exert local effects ranging from modulating gut motility and secretion to cell signaling [35, 36]. Members of the gut microbiota can synthesize neurotransmitters: Lactobacilli and Bifidobacteria produce GABA [37-41]; Escherichia coli (E. coli) produce 5-HT and dopamine $[42,43]$; Lactobacilli produce acetylcholine [44], and 
many more microbial taxa contribute to the synthesis and release of other molecules with neuroactive properties. In fact, gut microbiota absence is associated with significant reductions in intestinal levels of neurotransmitters like norepinephrine [45], 5-HT [32], and GABA [46]. While recolonization can re-establish normal neurotransmitter concentrations, it is not clear if this restoration of neurotransmission is due to bacterially derived products or due to stimulation of neurotransmitter producing host intestinal cells [47]. An example of the latter is 5-HT, whose intestinal concentrations are maintained by enterochromaffin cells, which express the enzyme tryptophan hydroxylase upon stimulation by gut metabolites such as SCFAs and secondary bile acids [48].

It is now established that peripheral production of neurotransmitters by the gut microbiome may alter brain chemistry and influence behavior (Table 2). While there is no evidence that gut-derived neurotransmitters reach the brain, these compounds may influence CNS signaling by cofeeding of other commensal bacteria and modulation of local host gut physiology upon absorption into the bloodstream. For example, Clarke et al. [49] showed that male germ-free mice exhibit anxiety-like behaviors as well as altered neurotransmitter (5-HT and 5-hydroxyindole acetic acid (5-HIAA)) abundance in the hippocampus. These central alterations were accompanied by an elevation in plasma tryptophan concentrations, suggesting that the peripheral tryptophan metabolism is influenced by microbiota, that also influence CNS neurotransmitter systems. While abnormal anxiety behavior was normalized by conventionalization in adulthood, the neurochemical imbalances in male germ-free mice persisted, indicating the profound effects of the gut microbiota on the development of neurotransmission [49]. The concentrations of dopamine and norepinephrine were also increased in the brains of germfree mice in a separate study [17]. Additionally, a study chronically administering $L$. rhamnosus to mice reported changes in $\mathrm{GABA}_{A}$ and $\mathrm{GABA}_{B}$ receptor expression as well as in the levels of brain activity, accompanied by a reduction in anxiety and depression-like symptoms [50]. Similarly, the GABA-producing L. brevis FPA3709 had an antidepressant effect when administered to rats [51]. Lower circulating concentrations of $5-\mathrm{HT}[32,48]$, dopamine [52] and GABA [53] have been observed in germ-free mice. This finding suggests that the gut microbiota may modulate neurotransmission via the bloodstream. Although enhanc-

TABLE 2. Studies investigating the effects of treatment with microbial cultures on neurotransmission and behavior.

\begin{tabular}{|c|c|c|c|c|}
\hline Treatment & Species or strain & Behavioral outcomes & Molecular mechanisms & Reference \\
\hline $\begin{array}{l}\text { L. rhamnosus } \\
\text { (109 cfu daily for } \\
28 \text { days) }\end{array}$ & $\begin{array}{c}\text { Adult male } \\
\text { BALB/c mice } \\
\text { (10-11 weeks) }\end{array}$ & $\begin{array}{l}\downarrow \text { anxiety and depressive-like } \\
\text { behavior in OFT, SIH, EPM, fear } \\
\text { conditioning (contextual and } \\
\text { cued), and FST after L. rhamno- } \\
\text { sus chronic adnimistration; } \\
\text { vagotomy prevented the anxio- } \\
\text { lytic and antidepressant effects } \\
\text { of } L \text {. rhamnosus }\end{array}$ & $\begin{array}{l}\text { Changes in expression of } \\
\text { GABAA } 2 \text { and GABAB1b mRNA } \\
\text { after L. rhamnosus chronic ad- } \\
\text { ministration; vagotomy alone } \\
\text { was sufficient to increase } \\
\text { GABAA } 2 \text { mRNA in the hippo- } \\
\text { campus but prevented further } \\
\text { changes induced by } L \text {. rhamnosus }\end{array}$ & {$[55]$} \\
\hline $\begin{array}{l}\text { B. infantis } \\
\text { (daily for } 14 \\
\text { days) }\end{array}$ & $\begin{array}{l}\text { Sprague-Dawley } \\
\text { rats }\end{array}$ & $\begin{array}{c}\text { no effect on depressive-like } \\
\text { behavior }\end{array}$ & $\begin{array}{l}\downarrow \text { inflammatory markers (IFN- } \gamma \text {, } \\
\text { TNF- } \alpha \text { and IL-6 cytokines); } \uparrow \\
\text { plasma tryptophan and kynurenic } \\
\text { acid; } \downarrow \text { concentrations of 5-HIAA } \\
\text { (frontal cortex) and DOPAC } \\
\text { (amygdaloid cortex) }\end{array}$ & [58] \\
\hline $\begin{array}{l}\text { L. rhamnosus } \\
(1 \times 109 \text { cfu dai- } \\
\text { ly for } 4 \text { weeks })\end{array}$ & $\begin{array}{l}\text { male } B A L B / c \\
\text { mice }\end{array}$ & $\begin{array}{l}\downarrow \text { in anxiety and depression- } \\
\text { related behaviors }\end{array}$ & $\begin{array}{l}\uparrow \text { glutamate }+ \text { glutamine and } \uparrow \\
\text { total } \mathrm{N} \text {-acetyl aspartate }+\mathrm{N}- \\
\text { acetyl aspartyl glutamic acid at } 2 \\
\text { weeks; } \uparrow \text { GABA at } 4 \text { weeks }\end{array}$ & {$[50]$} \\
\hline $\begin{array}{l}\text { L. brevis FPA } \\
3709 \text { (48-h fer- } \\
\text { mented black } \\
\text { soybean milk at } \\
\text { a dosage of } 35 \\
\mathrm{mg} / \mathrm{kg} \text { b.w. in- } \\
\text { cluding } 2.5 \mathrm{mg} \\
\text { GABA/kg b.w. } \\
\text { for } 28 \text { days) }\end{array}$ & $\begin{array}{l}\text { Male Sprague- } \\
\text { Dawley rats }\end{array}$ & $\begin{array}{c}\downarrow \text { in depressive behavior in FST } \\
\text { comparable to the effect of } \\
\text { fluoxetine }\end{array}$ & 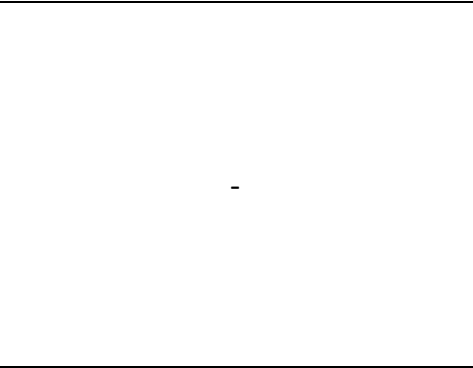 & [51] \\
\hline
\end{tabular}

5-HIAA: 5-Hydroxyindoleacetic Acid; cfu: Colony-Forming Unit; DOPAC: 3,4-Dihydroxyphenylacetic Acid; FST: Forced Swim Test; EPM: Elevated Plus Maze; GABA: Gamma-Aminobutyric Acid; IFN- $p$ : Interferon Gamma; IL-6: Interleukin-6; OFT; Open Field Test; SIH: StressInduced Hyperthermia; TNF- $\alpha$ : Tumor Necrosis Factor Alpha. 
ing 5-HT production in the gut does not result in an increase in central concentrations [47], central concentrations of 5-HT can be enhanced by increasing the concentrations of its precursor tryptophan in the GI tract $[16,54]$. These findings have an important relevance in the context of depression, as they demonstrate the possibility of modulating central serotonergic neurotransmission through non-invasive interventions that target the gut microbiome.

Microbial metabolites can also have an impact on central neurotransmission by activating afferent nerve fibers. The involvement of the vagus nerve in gut-brain communication was demonstrated by Bravo et al. [55]. This work showed that administration of probiotics like L. rhamnosus had anxiolytic and antidepressant effects and induced significant changes in GABA receptor expression in the brain of normal, but not vagotomized, mice [55]. Neurotransmitters produced in the gut may also influence brain function through the modulation of the immune system. There have been reports of 5-HT activating cells of the immune system [56], and of GABA dampening intestinal inflammation [57]. Upon chronic administration of the probiotic $B$. infantis, naïve rats displayed an attenuation of inflammatory markers such as interferon- $\gamma$ (IFN- $\gamma$ ), tumor necrosis factor- $\alpha$ (TNF- $\alpha$ ) and interleukin-6 (IL-6) [58]. Since a concomitant increase in circulating tryptophan and kynurenic acid and decrease in central 5-HIAA and 3,4-dihydroxyphenylacetic acid (DOPAC) were described, the dampening of the inflammatory response may be ascribed to a change in neurotransmitter production and availability [58]. Alternatively, neurotransmitters produced by the gut microbiota can inhibit cytokine production through local stimulation of the vagus nerve [59].

These studies suggest that neurotransmitters produced, either directly or indirectly, by gut bacteria may influence emotional behavior by binding specific receptors in the CNS, or peripheral receptors on neural or immune cells. A wider range of bacterially-derived, bioactive, transmitterlike molecules may exist whose effects on depressive symptoms have not been investigated to the same extent as classic neurotransmitters. These molecules include histamine, gasotransmitters (e.g. nitric oxide, ammonia), neuropeptides, endocannabinoids, steroids [60], and it is likely that more will be identified in the future. This communication between bacterial and host metabolism of neurotransmitters is bidirectional in nature: in addition to synthesizing neurotransmitters that are able to alter host physiology, gut microbes can also respond to neurotransmitters produced by the host, which influence bacterial growth and development [61].

\section{SCFAs}

SCFAs are small organic compounds produced in the cecum and colon by anaerobic fermentation of predominantly indigestible dietary carbohydrates that cross-feed other bacteria and are readily absorbed in the large bowel [62]. SCFAs are involved in digestive, immune and central function, although different accounts on their impact on behavior exist. Administration of the three most abundant SCFAs (acetate, butyrate and propionate) was shown to alleviate symptoms of depression in mice [63]. In support of their involvement with the etiology of depression, a depletion of butyrate, acetate and propionate was reported in MDD patients $[8,10,64,65]$, and a high abundance of butyrateproducing bacteria, like Faecalibacterium and Coprococcus spp., was detected in subjects with higher quality of life indicators [11]. The genera Faecalibacterium and Coprococcus are Gram-positive, anaerobic bacteria which ferment dietary fibers to produce SCFAs. Faecalibacteria are one of the most abundant gut microbial genera, with important immunological functions and clinical relevance for a variety of diseases, including MDD [8].

SCFAs are able to bind and activate the G proteincoupled receptors GPR43 (free fatty acid receptor 2 (FFAR2)) and GPR41 (FFAR3), as well as the less common CPR164 and GPR109a (also known as OR51E1 and HCAR2 respectively) [66]. These receptors are ubiquitously expressed by several organs in the body, including enteroendocrine cells, adipocytes, immune cells and neurons [66], suggesting that SCFAs may alter behavior by direct stimulation of neural pathways, or through the indirect central effect of neuroendocrine and immune activation.

Locally, SCFAs promote gut health by modulating energy regulation, glucose metabolism and lipid homeostasis [67] and regulate intestinal barrier integrity by enhancing the expression of tight junctions (particularly butyrate, see [68]). By binding to FFAR2, SCFAs control feeding behavior by stimulating the production of the anorexigenic hormones glucagon-like peptide-1 (GLP-1) and peptide YY (PYY) by enteroendocrine cells [69-71], and of leptin by adipocytes [72]. As previously stated, SCFAs also contribute to the synthesis and release of peripheral neurotransmitters (like 5-HT and acetylcholine) by enterochromaffin cells, in a process that is thought to be mediated by OR51E1 [73], and norepinephrine by sympathetic neurons, via stimulation of FFAR2 and FFAR3 [74]. Recent work has demonstrated the presence of FFAR3 in the mouse vagal ganglia [75], suggesting a role for SCFAs in establishing visceral reflexes. The ability of SCFAs to activate vagal fibers and induce activity in the hypothalamus has been implicated as the neural basis of their central anorexigenic effect [76]. In addition to their local action in the gut and in the peripheral nervous system, SCFAs can act directly on central receptors due to their ability to diffuse passively or actively (via monocarboxylate transporters) across the $\operatorname{BBB}[77,78]$. SCFAs like acetate can directly modulate appetite by binding to and activating receptors in the hypothalamus [34]. Interestingly, appetite suppression by propionate involves the attenuation of neural activity in regions of the brain reward system (i.e. caudate and nucleus accumbens) [79], a circuitry that is also dysfunctional in patients with depression [80]. Since no change in circulatory concentrations of PYY or GLP-1 were observed, it is likely that signaling via the vagus nerve or central receptors is responsible for the central effects of propionate. In addition, in vitro studies show both propionate and butyrate, but not acetate, can modulate the permeability of the BBB, protecting against the increased permeability caused by LPS [30]. 
Binding of SCFAs to FFAR2, FFAR3, GPR109a and Olfr78 receptors expressed by immune cells contributes to the development and function of the immune system [81]. For example, microglia abnormalities in germ-free mice can be reversed by SCFA administration in a FFAR2-dependent manner [82]. The observation that SCFAs generally dampen inflammation [83, 84] suggests that the antidepressant effects of SCFAs may be partly accounted for by their antiinflammatory properties. However, while butyrate was shown to suppress neuroinflammation by acting on microglial GPR109a receptors [68], propionic acid was shown to activate microglia and induce reactive astrogliosis in rats [85] and to promote immune cell recruitment in a FFAR3mediated pathway [86]. These observations suggest a complex relationship between SCFAs and immune function. Moreover, while central butyrate promotes neurogenesis and angiogenesis $[87,88]$ and contributes to tight junction expression and BBB structural integrity [68], intraventricular infusions of propionate contributed to mitochondrial dysfunction and oxidative stress by inducing lipid peroxidation, protein carbonylation and metabolic alterations in the rat brain $[85,89,90]$. However, it must be noted that many of these preclinical studies used supraphysiological doses of propionate and that, while intraventricular injections elicited a strong effect on the brain, such changes do not occur if SCFAs were administered peripherally.

SCFAs are strong epigenetic modulators that can control the accessibility of genetic material for DNA methylation and inhibition of histone deacetylation. A rodent study revealed the DNA methylation properties of sodium butyrate, the salt form of butyric acid [91]. This mechanism is dependent on ten-eleven translocation (TET) proteins, which catalyze the hydroxylation of cytosine residue $(5 \mathrm{mC})$ into 5-hydroxymethylcytosine $(5 \mathrm{hmC})$. $5 \mathrm{hmC}$ can then mediate active DNA demethylation. While depressed mice exhibited low levels of the TET methylcytosine dioxygenase 1 (TET1), mice treated with sodium butyrate showed a normalization in 5-hydroxymethylation levels by TET1, resulting in BDNF gene overexpression [91]. Depression is often characterized by altered histone deacetylase (HDAC) activity, and several studies have demonstrated the epigenetic potential of different antidepressant medications [92] Butyrate has been identified as a HDAC inhibitor for HDAC1, HDAC2 and HDAC7 [93], and its systemic administration induced histone acetylation in the hippocampus and frontal cortex in mice [94]. The beneficial effect of sodium butyrate on mood was shown in rodent models of depression either alone [95-97] or in conjunction with antidepressant drugs [94, 98]. For example, repeated injections of sodium butyrate reversed the LPS-induced activation of microglia and depressed mood in mice [99]. This antidepressant effect was mediated by the acetylation of hippocampal histones $\mathrm{H} 3$ and $\mathrm{H} 4$, which reduced the expression of Iba1, a marker of microglia activation [99]. Alternatively, Sun et al. [100] found that the beneficial effects of sodium butyrate on depressive behavior were mediated by an increase in 5-HT concentrations, reversal of hippocampal neuronal abnormalities, increased BDNF expression, and an upregulation of tight junction expression at the BBB
[100]. In line with these findings, sodium butyrate was reported to promote the expression of dopamine, adrenaline, and other neurotransmitter genes in a rat pheochromocytoma cell line [101]. Other investigations demonstrated that further effects of HDAC inhibition by butyrate included a reduction in neuroinflammation through modulation of microglia activation [102] and an enhancement in $N$ methyl-D-aspartate (NMDA) receptor activity [103].

The SCFA propionate also acts as a HDAC inhibitor [104], and intrarectal administration of sodium propionate was shown to improve despair behavior in rats [105]. The antidepressant effect of propionate was accompanied by an increase in norepinephrine, dopamine, tryptophan, 5-HIAA and 3-hydroxyanthranilic acid (3-HAA) in the prefrontal cortex, although no change was detected in 5-HT and 3-hydroxykynurenine (3-HK). The known ability of propionate (shared with butyrate) to promote dopamine and norepinephrine synthesis by enhancing the transcription of the tyrosine hydroxylase gene [101], may be the mechanism underlying these molecular and behavioral effects. Both butyrate and propionate may also contribute to dopaminergic function by inhibiting the expression of dopamine- $\beta$-hydroxylase, which catalyzes the conversion of dopamine into norepinephrine. Thus, the opposite effects of SCFAs on behavior may be explained by their action via independent mechanisms: for example, Li et al. [105] found that while butyrate modulated the expression of 5-HT (with slow-onset but long-term antidepressant action), propionate altered the expression of norepinephrine (with fast-acting, but short-term antidepressant action). However, propionate is also able to modulate serotonergic function by increasing the expression of tryptophan hydroxylase (TPH) [101], responsible for the conversion of tryptophan to $5-H T$. This finding is significant for unveiling the link between neuroinflammation and neurotransmitter production, as an increased TPH turnover induces an accumulation of kynurenine and neurotoxic metabolites like 3-HK [105]. Since altered tryptophan-kynurenine metabolism is characteristic of depression [106], this observation suggests that serotonergic function may be linked to antiinflammatory mechanisms. Indeed, oral administration of propionate was shown to result in a decrease in the neurotransmitters GABA, 5-HT, and dopamine, as well as in a range of biomolecular alterations which included increased oxidative stress (indicated by lipid peroxidation), altered energy metabolism, and higher pro-inflammatory markers like IL-6, TNF- $\alpha$, IFN- - , heat shock protein 70 and caspase 3 [107]. Several additional studies suggested that modulation of mood by SCFAs can occur via mechanisms involving the immune system, but the findings are contradictory. While butyrate has established anti-inflammatory effects including the inhibition of pro-inflammatory gene expression [108-110], propionate has been reported to have both anti- [111] and pro-inflammatory properties [112-114].

Despite this evidence (Table 3 ), results supporting the antidepressant potential of SCFAs are not consistent enough to be translated into medical practice. For example, cecal isobutyrate is reduced in response to administration of probiotics with antidepressant efficacy [115], and some 
TABLE 3. Studies investigating the effects of SCFAs on depressive-like behavior.

\begin{tabular}{|c|c|c|c|c|c|}
\hline Treatment & $\begin{array}{l}\text { Species or } \\
\text { strain }\end{array}$ & Model & Behavioral outcomes & Molecular mechanisms & Reference \\
\hline $\begin{array}{l}\text { Sodium butyr- } \\
\text { ate }(100 \mathrm{mg} / \mathrm{kg} \\
\text { or } 1.2 \mathrm{~g} / \mathrm{kg} \text {; ip; } 1 \\
\quad \text { or } 21 \text { days) }\end{array}$ & $\begin{array}{l}\text { 129SvEv x } \\
\text { C57BI/6 } \\
\text { mice (F1 } \\
\text { crosses) }\end{array}$ & - & $\begin{array}{l}\text { 个 immobility time and } \uparrow \\
\text { latency to consume peanut } \\
\text { butter chips in the novel } \\
\text { environment after acute } \\
\text { treatment with SB100; no } \\
\text { effect of chronic treatment }\end{array}$ & $\begin{array}{l}\uparrow \text { acH } 4 / \mathrm{H} 3 \text { and } \mathrm{acH} 3 / \mathrm{H} 3 \text { protein in } \\
\mathrm{HP} \text { after acute SB } 100 \text { and/or } 1.2 \\
\text { treatment, respectively; } \downarrow \text { acH } 4 / \mathrm{H} 3 \\
\text { (no changes in acH3/H3) in HP after } \\
\text { chronic SB100 administration }\end{array}$ & {$[95]$} \\
\hline $\begin{array}{l}\text { Sodium butyr- } \\
\text { ate ( } 1.2 \mathrm{~g} / \mathrm{kg} \text { ip; } \\
1 \text { or } 7 \text { days) }\end{array}$ & $\begin{array}{l}\text { Sprague- } \\
\text { Dawley rats }\end{array}$ & - & $\begin{array}{l}\downarrow \text { immobility time in rats } \\
\text { after repeated (but not } \\
\text { acute) SB administration; } \\
\text { no changes in OFT }\end{array}$ & $\begin{array}{c}\text { 个 Ttr and } \downarrow \text { Slc8a3, Casr, Htr2a, } \\
\text { Tcf12 and no changes in Sin3a, } \\
\text { Gnrhr, Crhr2, Bdnf, Slc8a2 gene ex- } \\
\text { pression in hippocampus after re- } \\
\text { peated SB treatment; } \uparrow \text { levels of } \\
\text { acH4-associated DNA at the Ttr } \\
\text { promotor region in HP of rats re- } \\
\text { peated treated with SB; } \uparrow ~ T t r \text { and } \\
\text { no changes in acH3/H3, acH4/H4 } \\
\text { protein level in HP after repeated SB } \\
\text { administration }\end{array}$ & [97] \\
\hline $\begin{array}{l}\text { Sodium butyr- } \\
\text { ate }(0.3 \mathrm{~g} / \mathrm{kg} \text { ot } \\
0.6 \mathrm{~g} / \mathrm{kg})\end{array}$ & ICR mice & CRS & $\begin{array}{l}\downarrow \text { anhedonia, time spent } \\
\text { in dark and immobility } \\
\text { time after SBO. } 6 \text { admin- } \\
\text { istration in CRS-treated } \\
\text { mice }\end{array}$ & $\begin{array}{l}\text { SB0.6 reverses CRS-induced de- } \\
\text { crease in acH3 level in HP }\end{array}$ & [96] \\
\hline $\begin{array}{l}\text { Fluoxetine (10 } \\
\mathrm{mg} / \mathrm{kg} \text {; oral) + } \\
\text { Sodium butyr- } \\
\text { ate }(300 \mathrm{mg} / \mathrm{kg} \text {; } \\
\text { ip) for } 21 \text { days }\end{array}$ & $\begin{array}{l}\text { Sprague- } \\
\text { Dawley } \\
\text { rats ( } 2 \\
\text { months) }\end{array}$ & - & $\begin{array}{l}\downarrow \text { time spent in social } \\
\text { grooming and frequency of } \\
\text { pouncing and } \uparrow \text { immobili- } \\
\text { ty time and immobility } \\
\text { events in PNFIx rats; } \uparrow \\
\text { latency to approach center } \\
\text { and } \downarrow \text { time spent in the } \\
\text { center and path length in } \\
\text { the center in PNFIx ani- } \\
\text { mals; postnatal treatment } \\
\text { with SB and adult fluoxe- } \\
\text { tine (AFIx) treatment pre- } \\
\text { vented the PNFIx-evoked } \\
\text { behavioral changes }\end{array}$ & $\begin{array}{c}\text { 个 Hdac4, Ppp2r2b, Gal, Dcx, Kcnh2, } \\
\text { Grm8, Elkl and } \downarrow \text { mTOR, Gnai1, } \\
\text { Prkcc, Hcnl, Notch3 and Avpr2 mRNA } \\
\text { levels in HP of PNFlx rats;co- } \\
\text { administration of SB prevented the } \\
\text { PNFlx-evoked dysregulation of } \\
\text { Hdac4 and mTOR, but not Gnai1, } \\
\text { Prkcc and Hcnl in HP; AFlx admin- } \\
\text { istration did no alter hippocampal } \\
\text { expression of Hdac4, mTOR, Gnai1, } \\
\text { Hcnland Prkcc; } \uparrow \text { acetylation of H3 } \\
\text { and H4 at the Hdac4 promoter and } \\
\uparrow \text { HDAC4 enrichment in Gnai1 and } \\
\text { mTOR promoter in HP of PNFlx rats } \\
\text { and normalization after adult fluoxe- } \\
\text { tine treatment; } \downarrow \text { mTOR protein } \\
\text { level in HP of PNFlx rats and no } \\
\text { changes after AFlx treatment }\end{array}$ & [98] \\
\hline $\begin{array}{l}\text { Sodium butyr- } \\
\text { ate }(0.4 \mathrm{~g} / \mathrm{kg} \text {; ip) } \\
\text { twice a day for } \\
23 \text { days }\end{array}$ & $\begin{array}{l}\text { Male FRL and } \\
\text { FSL rats ( } 3 \\
\text { months) }\end{array}$ & - & $\begin{array}{l}\text { chronic NaB-treatment } \\
\text { rescued the FSL depres- } \\
\text { sion-like phenotype; } \downarrow \\
\text { immobility time }\end{array}$ & $\begin{array}{l}\text { The FSL-NaB group exhibited } \uparrow \text { Tet1 } \\
\text { mRNA (and protein) ; } \downarrow \text { Dnmt1 } \\
\text { mRNA (but not protein) levels in the } \\
\text { FSL-NaB group; } \downarrow \text { hmC levels at the } \\
\text { Bdnf P4 locus; hypermethylation of } \\
\text { Bdnf P4 compared to FRL-Veh; the } \\
\text { NaB-dependent increase in } 5 \text { hmC } \\
\text { levels in Bdnf P4 of FSL was associat- } \\
\text { ed with DNA hypomethylation at the } \\
\text { same locus; NaB-dependent increase } \\
\text { in TET1 and 5hmC levels in the FSL } \\
\text { group was associated with a Bdnf P4 } \\
\text { overexpression }\end{array}$ & [91] \\
\hline $\begin{array}{l}\text { Sodium butyr- } \\
\text { ate }(500 \mathrm{mg} / \mathrm{kg} \text {, } \\
\text { i.p.) twice a day } \\
\text { for } 7 \text { days }\end{array}$ & $\begin{array}{l}\text { Wistar rats } \\
\text { ( } 2 \text { months) }\end{array}$ & $\begin{array}{l}\text { maternal } \\
\text { deprivation } \\
\text { or CMS }\end{array}$ & $\begin{array}{c}\downarrow \text { depressive-like behavior } \\
\text { in FST }\end{array}$ & $\begin{array}{l}\text { 个 tricarboxylic acid cycle anzyme } \\
\text { (succinate dehydrogenase and mal- } \\
\text { ate dehydrogenase) and mitochon- } \\
\text { drial chain complexes (I, II, II-III and } \\
\text { IV) activity in the striatum }\end{array}$ & {$[103]$} \\
\hline
\end{tabular}


TABLE 3 (continued). Studies investigating the effects of SCFAs on depressive-like behavior.

\begin{tabular}{|c|c|c|c|c|c|}
\hline Treatment & $\begin{array}{l}\text { Species or } \\
\text { strain }\end{array}$ & Model & Behavioral outcomes & Molecular mechanisms & Reference \\
\hline Propionate & $\begin{array}{l}\text { Sprague- } \\
\text { Dawley rats }\end{array}$ & CUMS & $\begin{array}{l}\text { Improved performance at } \\
\text { the SPT and OFT; short- } \\
\text { term antidepressant-like } \\
\text { effects. }\end{array}$ & $\begin{array}{l}\text { Restored plasma levels of propionic } \\
\text { acid; } \uparrow N E, D A, T R P, 5-H I A A \text {, and 3- } \\
\text { HAA in the PFC (no effects on 5-HT } \\
\text { and 3-HK) were not; } \downarrow \text { turnover of } \\
\text { TRP to KYN (calculated as KYN/TRP) } \\
\text { and } \downarrow \text { turnover of DA to HVA (calcu- } \\
\text { lated as HVA/DA); } \uparrow \text { abundance of } \\
\text { DOPAC and 3-MT, but no change in } \\
\text { HVA; no effect on turnover of 5-HT } \\
\text { to 5-HIAA (calculated as 5-HIAA/5- } \\
\text { HT); } \uparrow \text { turnover of KYN to 3-HK }\end{array}$ & [105] \\
\hline $\begin{array}{c}\text { Sodium butyr- } \\
\text { ate }(200 \mathrm{mg} / \mathrm{kg}) \\
\text { or fluoxetine ( } 20 \\
\mathrm{mg} / \mathrm{kg})\end{array}$ & $\begin{array}{c}\text { Male } \\
\text { C57BL/B6 mice }\end{array}$ & CUMS & $\begin{array}{l}\uparrow \text { sucrose intake in SPT; } \uparrow \\
\text { locomotor activities in } \\
\text { OFT; decreases immobility } \\
\text { time in TST and FST }\end{array}$ & $\begin{array}{c}\text { decreases histological abnormalities } \\
\text { in hippocampal neurons; } \uparrow \text { BDNF } \\
\text { expression; } \uparrow \text { Occludin and ZO-1 } \\
\text { protein levels }\end{array}$ & [100] \\
\hline $\begin{array}{c}\text { Sodium butyr- } \\
\text { ate }(1.2 \mathrm{~g} / \mathrm{kg} \text { or } \\
0.2 \mathrm{~g} / \mathrm{kg} \text {, i.p.); } \\
\text { fluoxetine }(10 \\
\mathrm{mg} / \mathrm{kg}, \text { i.p. })+\mathrm{SB} \\
(0.6 \mathrm{mg} / \mathrm{kg} \text {, } \\
\text { i.p.) acutely of } \\
\text { chronically ( } 28 \\
\text { days) }\end{array}$ & $\begin{array}{l}\text { male and } \\
\text { female } \\
\text { C57BL/6J } \\
\text { mice } \\
\text { (9-22 weeks) }\end{array}$ & - & $\begin{array}{c}\text { improved performance at } \\
\text { the TST }\end{array}$ & $\begin{array}{l}\text { 个 histone acetylation in the brain; } \\
\text { 个 BDNF in mouse frontal cortex }\end{array}$ & [94] \\
\hline
\end{tabular}

3-HAA: 3-Hydroxyanthranilic Acid; 3-HK: 3-Hydroxyanthranilic Acid; 3-MT: 3-Methoxytyramine; 5-HIAA: 5-Hydroxyindoleacetic Acid; 5hmc: 5-Hydroxymethylcytosine; 5-HT: 5-Hydroxytryptamine; Ach4/H3: Acetylated Histone H3/4; Avpr2: Arginine Vasopressin Receptor 2; Casr: Calcium-Sensing Receptor; CMS: Chronic Mild Stress; Crhr2: Corticotropin Releasing Hormone Receptor 2; CRS: Chronic Restraint Stress; CUMS: Chronic Unpredictable Mild Stress; DA: Dopamine; Dcx: Dublecortin; Dnmt1: DNA (Cytosine-5)-Methyltransferase 1; DOPAC: 3,4-Dihydroxyphenylacetic Acid; Elkl: ETS Domain-Containing Protein; FRL: Flinders Sensitive Line; FSL: Flinders Resistant Line; FST: Forced Swim Test; Gal: Galanin; Gnai1: G Protein Subunit Alpha 11; Gnrhr: Gonadotropin Releasing Hormone Receptor; Grm8: Glutamate Metabotropic Receptor 8; Hcnl: Hyperpolarization-Activated Cyclic Nucleotide-Gated Channel 1; Hdac4: Histone Deacetylase 4; Htr2a: 5 Hydroxytryptamine Receptor 2A; HVA: Homovanillic Acid; Kcnh2: Potassium Voltage-Gated Channel Subfamily H Member 2; KYN: Kynurenine; Mtor: Mammalian Target of Rapamycin; NE: Norepinephrine; Notch3: Neurogenic Locus Notch Homolog Protein 3; OFT: Open Field Test; PFC: Prefrontal Cortex; Ppp2r2b: Protein Phosphatase 2 Regulatory Subunit Beta; Prkcc: Protein Kinase C Gamma; Sin3a: SIN3 Transcription Regulator Family Member A; SIc8a3: Solute Carrier Family 8 Member A3; SPT: Sucrose Preference Test; Tcf12: Transcription Factor 7-Like 2; TET1: Ten-Eleven Translocation 1; TRP: Tryptophan; TST: Tail Suspention Test; Ttr: Transthyretin; ZO-1: Zonula Occludens-1.

studies have failed to detect significant abnormalities in the abundance of butyrate in MDD patients $[116,117]$ or animal models of depression [105] compared to controls. Such discrepancies may be partly due to the highly volatile nature of SCFA and to their sensitivity to the conditions of storage and tissue extraction [118], which can affect quantification and hinder comparable results across studies. In addition, controversies exist regarding the appropriate control for studies that administer SCFA in the form of salt. Although the ideal control for this experimental model should be sodium matched, some behavioral and/or physiological effects cannot be excluded [63], especially in the light of recent findings showing that a diet high in salt alters gut microbiota composition and reduces butyrate production [119]. As for propionate, its dysregulation in animal models of depression has been consistently demonstrated $[64,105]$, but its neurotoxic effects and the behavioral deficits elicited at excessive doses imply that more in- depth knowledge of the underlying mechanisms are required before a targeted intervention can be developed.

For example, there is still a lack of consensus regarding the mode of action and receptor specificity of SCFAs. In addition, it remains unclear how well the microbial production of SCFAs in the gut parallels CNS availability. It is known that lumen concentrations of SCFAs are highly variable among individuals, and can range between 20-140 $\mathrm{mM}$ depending (among other factors) on fiber content of the diet, microbiota composition, rate of absorption and site of measurement in the gut $[120,121]$. Absorbed by colonocytes, SCFAs are transported to the liver and then enter the systemic circulation in much lower concentrations $(0.1-10 \mathrm{mM})[122,123]$. Although it remains unclear how well the microbial production of SCFAs in the gut relates to CNS availability, rodent studies have shown that $\sim 3 \%$ of acetate administered intravenously reaches the CNS [34], suggesting that only a small proportion of the SCFAs absorbed from the gut reaches the brain. Increasing 
bacterial production of SCFAs by means of higher fiber intake (reviewed in [124, 125]) and pre- or probiotics use $[126,127]$ have been shown to effectively enhance the concentrations of SCFAs in the gut. The question remains as to whether direct SCFA supplementation is more effective than strategies targeting the gut microbiota. While direct supplementation with SCFAs may overcome problems related to competition of probiotic strains with resident bacterial strains, care has to be taken to elucidate the effects of SCFA depending on whether it is administered acutely (i.e. via supplementation) or chronically (i.e. via microbial production). Thus, the best strategy to implement the known beneficial effects of SCFAs on mood has still to be elucidated.

\section{Tryptophan metabolites}

Tryptophan is an essential amino acid involved in protein synthesis [128]. Its metabolic breakdown by host (TDO and IDO) and bacterial enzymes (tryptophanase) give rise to neuroactive molecules with established mood-modulating properties, including $5-\mathrm{HT}$, kynurenine and indole. It is well-established that dietary intake of tryptophan can modulate central concentrations of 5-HT in humans [129, 130], and that tryptophan depletion exacerbates depressive symptoms in healthy individual at risk for depression [131, 132], as well as remitted [133-135] and currently depressed patients $[136,137]$. However, less than $5 \%$ of tryptophan is converted into 5-HT along the methoxyindoles pathway by the enzyme tryptophan hydroxylase; the remaining $95 \%$ is metabolized along the kynurenine pathway by the enzymes TDO and IDO. Kynurenine can be further metabolized into kynurenic acid (KYNA) or, alternatively, into quinolinic and picolinic acids via the nicotinamide adenine dinucleotide (NAD) pathway. KYNA is an NMDA and $\alpha 7$ nicotinic acetylcholine receptor antagonist; quinolinic and picolinic acids are NMDA agonists with neurotoxic and pro-depressant effects [138]. Over-stimulation of the kynurenine pathway leads to increased lipid peroxidation and inflammation, due to quinolinic and picolinic acids and free radical generation (3-hydroxykynurenine and 3-hydroxyanthranilic acid) $[139,140]$. Conversely, production of stress hormones (i.e. cortisol) and proinflammatory cytokines (i.e. interferons, TNF- $\alpha$, interleukins) stimulate TDO and IDO formation respectively, enhancing kynurenine output at the expenses of 5-HT synthesis. In turn, the weakening of the inhibitory feedback of 5-HT on cortisol production contributes to the worsening of this cycle [141]. Therefore, disturbances in tryptophan metabolism (i.e. the shunt of tryptophan from 5-HT to kynurenine synthesis) may be partly responsible for the mood, cognitive and sleep disturbances typical of depression [141].

The mechanisms that control the uptake of tryptophan into the brain are not fully understood: these include the proportion of circulatory tryptophan that is bound to albumin (which is unable to cross the BBB), as well as the competition with other neutral amino acids for its transport through the BBB [142], but other factors are likely to be involved. Studies on germ-free animals have demonstrated the role of the microbiome in mediating the behavioral effects of tryptophan metabolism, suggesting a potential additional mechanism. Upon colonization of these animals with tryptophan-metabolizing bacteria, a decrease in tryptophan and an increase in hippocampal 5-HT concentrations was noted, accompanied by reduced anxiety-like behaviors $[2,49]$. Studies have shown that the metabolic activity of the gut microbiota on dietary tryptophan produces biologically active signaling molecules, such as indole and its derivatives. Indole is an aromatic amino acid produced through the microbial metabolism of tryptophan by bacteria expressing the enzyme tryptophanase (e.g. E. coli [143] and other strains [144]). In microbial communities, indole is used as a quorum-sensing signal to coordinate collective behaviors like spore formation, plasmid stability and drug resistance [144]. Moreover, it plays an important role in gut physiology as it stimulates enteroendocrine L cells to secrete GLP-1 [145] and regulates gut barrier permeability [146]. In addition, oxindole and isatin (2,3-dioxoindole), products of indole oxidation and conjugation respectively, have been described as neuroactive signaling molecules able to modulate motor function and emotional behavior. Oxindole is a strong inhibitor of motor activity, and it is known to result in loss of the righting reflex, hypotension, and reversible coma [147]. Isatin increases water intake and decreases food intake. A rodent study using antagonists selective to specific receptors highlighted the possibility of these effects being mediated by the $5-\mathrm{HT}_{3}$ receptor and the dopamine $\mathrm{D}_{2}$ receptor [148]. The action of isatin on $5-\mathrm{HT}_{3}$ and atrial natriuretic peptide (ANP) receptors may also be responsible for the negative effect of this compound on memory formation [149]. Additionally, isatin is an endogenous monoamine oxidase (MAO) B inhibitor and a benzodiazepine receptor antagonist. As such, it has an established anxiogenic profile in both mice and rats $[150,151]$, and in turn, its production is drastically increased in conditions of stress. However, it is important to state that modifications in the chemical structure of indole and derivatives have been reported to drastically change the behavioral properties of these compounds, and even confer some antidepressant actions [152].

Based on research studies investigating the behavioral effects of indole and its metabolites, several pathways may mediate the neuroactive potential of indoles (Table 4). Enhanced tryptophan catabolism into indoles may mimic the reversible effect of a tryptophan-deficient diet, which is also associated with reduced 5-HT availability and increased neuroinflammation [153]. Other mechanisms may include direct effects of indole metabolites on central receptors, activation of the vagus nerve by gut bacteria or their metabolites, and stimulation of a neuroinflammatory state. A study by Jaglin et al. [154] showed how the effects of indole on physiology and behavior were mediated by different pathways depending on whether they were administered chronically or acutely. Acute administration of indole in the rat cecum caused a significant reduction in locomotion and an accumulation of indole metabolites in the brain, suggesting a possible direct role on central re- 
TABLE 4. Studies investigating the effects of indole metabolites on depressive-like behavior.

\begin{tabular}{|c|c|c|c|c|c|}
\hline Treatment & Species or strain & Model & Behavioral outcomes & $\begin{array}{l}\text { Molecular mech- } \\
\text { anisms }\end{array}$ & Reference \\
\hline $\begin{array}{l}\text { Isatin (15 mg/kg i.p. in } \\
\text { mice and } 20 \mathrm{mg} / \mathrm{kg} \text { i.p. } \\
\text { in rats); yohimbine ( } 2 \\
\mathrm{mg} / \mathrm{kg} \text { i.p. in mice and } \\
2.5 \mathrm{mg} / \mathrm{kg} \text { i.p. in rats) }\end{array}$ & $\begin{array}{l}\text { Male Charles } \\
\text { Foster rats and } \\
\text { Wistar mice }\end{array}$ & - & $\begin{array}{l}\text { 个anxiety in the OFT and } \\
\text { EPM in mice, and the SIT in } \\
\text { rats, comparable to yohim- } \\
\text { bine. } \downarrow \text { anxiolytic effects of } \\
\text { diazepam in the OFT }\end{array}$ & - & [150] \\
\hline $\begin{array}{c}\text { Isatin (0-160 mg/kg } \\
\text { i.p.) }\end{array}$ & $\begin{array}{l}\text { Male Sprague- } \\
\text { Dawley rats (90- } \\
100 \text { days) }\end{array}$ & - & $\begin{array}{c}\text { 个immobility in the OFT and } \\
\text { FST }\end{array}$ & - & [151] \\
\hline $\begin{array}{l}\text { Oxindole or isatin ( } 50 \text { or } \\
100 \mathrm{mg} / \mathrm{kg} \text {, i.p.) or in- } \\
\text { dole ( } 500 \mathrm{mg} / \mathrm{kg} \text { intra- } \\
\text { cecal administration); } \\
\text { inoculation with } 1 \mathrm{~mL} \text { of } \\
\text { BW25113 or JW3686 } \\
\text { bacterial cultures }\end{array}$ & $\begin{array}{l}\text { F344 male rats } \\
(2-2.5 \text { months })\end{array}$ & $\begin{array}{l}\text { Conventional, } \\
\text { SPF and GF }\end{array}$ & $\begin{array}{l}\text { Acute intra-cecal administra- } \\
\text { tion of indole induced } \\
\downarrow \text { motor activity and } \uparrow \text { con- } \\
\text { centrations of oxindole and } \\
\text { isatin in the brain. Chronic } \\
\text { overproduction of indole by } \\
\text { colonization with } E \text {. coli } \\
\text { caused no change in motor } \\
\text { activity and no detectable } \\
\text { oxindole or isatin in the } \\
\text { brain but } \uparrow \text { helplessness in } \\
\text { the TST and } \uparrow \text { anxiety in the } \\
\text { novelty test, EPM and OFT. }\end{array}$ & $\begin{array}{l}\text { 个eye blinking } \\
\text { frequency and } \\
\text { 个c-Fos protein } \\
\text { expression in the } \\
\text { dorsal vagal } \\
\text { complex }\end{array}$ & [154] \\
\hline $\begin{array}{l}\text { Tryptophan-depleted } \\
\text { diet with or without } \\
\text { tryptophan supplemen- } \\
\text { tation; I3S,IPA, IAld or } \\
\text { indole supplementation }\end{array}$ & $\begin{array}{l}\text { female C57BL/6J } \\
\text { mice (WT and } \\
\text { GFAP AhR- } \\
\text { deficient) }\end{array}$ & EAE & ${ }^{2}$ & $\begin{array}{l}\text { 个CCl} 2 \text { and Nos2 } \\
\text { expression in } \\
\text { astrocytes in } \\
\text { tryptophan de- } \\
\text { pleted group, } \\
\text { reverted by sup- } \\
\text { plementation; } \\
\text { administration of } \\
\text { I3S, IPA, IAld } \\
\text { activates AhR } \\
\text { and } \downarrow C c / 2 \text { and } \\
\text { Nos } 2 \text { expression }\end{array}$ & [153] \\
\hline
\end{tabular}

AhR: Aryl Hydrocarbon Receptor; Ccl2: C-C Motif Chemokine Ligand 2; EAE: Experimental Autoimmune Encephalomyelitis; EPM: Elevated Plus Maze; FST: Forced Swim Test; GF: Germ Free; GFAP: Glial Fibrillary Acidic Protein; I3S: Indoxyl-3-sulfate; IAld: Indole-3-aldehyde; IPA: Indole-3-propionic acid; Nos2: Nitric Oxide Synthase 2; OFT: Open Field Test; SIT: Social Interaction Test; SPF: Specific Pathogen Free; WT: Wild Type.

ceptors. In contrast, chronic exposure to indole, achieved by the colonization of germ-free rats with $E$. coli, exacerbated anxiety-like and helplessness (i.e. depression-like) behaviors, but had no effect on motor activity [154]. In contrast to acutely administered animals, these colonized rats did not exhibit increased oxindole and isatin in the brain, nor increased circulatory corticosterone. These findings suggest that the behavioral alterations induced by chronic indole production (via colonization with indoleproducing $E$. coli) are not mediated by the action of indole or its metabolites on central receptors or on the HPA axis [154]. A reduction in eye blinking frequency was detected, suggesting the involvement of the vagus nerve in eliciting the anxiogenic and depressive-like behaviors described [154].

Indole and its derivatives (e.g. indoxyl-3-sulfate (I3S), indole-3-propionic acid (IPA) and indole-3-aldehyde (IAld)) are able to activate the aryl hydrocarbon receptor (AhR) $[153,155]$, with a subsequent inhibitory effect on neuroinflammation. Rothhammer et al. [153] showed in mice that were either supplemented with indole and related compounds or treated with tryptophanase, that neuroinflammation was reduced via activation of the AhR on astrocytes. This was attributed to increased expression of suppressor of cytokine signaling 2 (Socs2), and a subsequent inhibition of the transcription factor NF-kB.

Our understanding of the physiological and pathological role of indoles is hindered by the existence of a high number of indole derivatives, with diverse and dynamic actions. For example, IAld triggers the release of the antiinflammatory cytokine IL-22 [156], IPA regulates intestinal barrier function via pregnane $X$ receptor (PXR) [157] and is protective against DNA damage, lipid peroxidation and amyloid- $\beta$ deposition in the brain $[158,159]$, and I3S is 
cytotoxic and triggers free radical production [160]. Additionally, there is a very small number of studies aimed at investigating the effect of these bioactive compounds on behavior. Given the tight link between tryptophan metabolism and mood, it is important to investigate the role of these molecules in order to understand the underlying mechanisms of this disease.

\section{Lactate}

Lactate is an organic acid arising from both mammalian host processes and the fermentation of dietary fibers by lactic acid bacteria (e.g., L. lactis, L. gasseri, and L. reuteri), Bifidobacteria and Proteobacteria [161]. Lactate can be converted by several bacterial species to SCFAs contributing to the overall pool. Although present in the gut at low levels, lactate is absorbed into the bloodstream [162] and can cross the BBB [163]. Lactate has an established role in central signaling: in the brain, it is used as an energy substrate by neurons (due to its ability to be metabolized into glutamate) [164], it contributes to synaptic plasticity, and underlies memory formation $[165,166]$. Both rodent and human studies support an association between de- pression and lactate abnormalities (Table 5). Increased concentrations of urinary lactate were measured in patients suffering from severe MDD compared to controls [167]. Interestingly, compared to conventionally colonized mice, germ-free mice exhibit elevated hippocampal concentrations of lactate, but decreased concentrations in the frontal cortex. In contrast, germ-free rats exhibit higher frontal concentrations of lactate than conventional rats [168].

A potential mechanism through which lactate can modulate emotional behavior is through direct activation of the receptor GPR81 (also known as hydroxycarboxylic acid receptor 1 or HCA1), expressed in the hippocampus, neocortex and cerebellum [169]. The involvement of GPR81 in mood disorders has been suggested by Shoblock et al. [170]. However, through GPR81 activation, lactate modulates lipid and glucose metabolism, exerts an antiinflammatory effect (also mediated by ARRB2) [171], and inhibits GABAergic neurotransmission [172].

An alternative, and significantly more explored, mechanism explaining the effect of lactate on depressive behavior is epigenetic regulation of depression-related genes. An

TABLE 5. Studies investigating the effects of lactate on depressive-like behavior.

\begin{tabular}{|c|c|c|c|c|c|}
\hline Treatment & $\begin{array}{l}\text { Species or } \\
\text { strain }\end{array}$ & Model & Behavioral outcomes & Molecular mechanisms & Reference \\
\hline $\begin{array}{l}\text { L-lactate (1 } \\
\text { g/kg, ip, either } \\
\text { acute or chron- } \\
\text { ic (daily for } 3 \\
\text { weeks)) }\end{array}$ & $\begin{array}{l}\text { C57BI/6 mice } \\
\text { (8-10 weeks) }\end{array}$ & $\begin{array}{l}\text { corticosterone } \\
\text { model of de- } \\
\text { pression (for } \\
\text { chronic exper- } \\
\text { iment only) }\end{array}$ & $\begin{array}{c}\text { Chronic treatment } \downarrow \\
\text { immobility in the FST } \\
\text { to a similar extent as } \\
\text { desipramine; chronic } \\
\text { treatment abolished } \\
\text { the } \\
\text { increased immobility } \\
\text { induced by corti- } \\
\text { costerone treatment } \\
\text { in the } \\
\text { FST and TST, reversed } \\
\text { the corticosterone- } \\
\text { induced decrease in } \\
\text { saccharin consump- } \\
\text { tion and decreased } \\
\text { the immobility time } \\
\text { in the open-space } \\
\text { forced swim model of } \\
\text { depression to a simi- } \\
\text { lar extent as } \\
\text { desipramine }\end{array}$ & $\begin{array}{l}\text { Acute effects: } \downarrow \text { GSK3 } \alpha \text { and GSK3 } \beta \\
\text { in the hippocampus; } \downarrow \text { phospho- } \\
\text { CREB levels in the hippocampus; } \\
\uparrow \text { hippocampal Arc, COX- } 2 \text { and } \\
\text { NOS1 mRNA expression; } \downarrow \text { COX-2 } \\
\text { mRNA in the hippocampus. Chronic } \\
\text { effects: } \uparrow \text { mRNA and protein levels } \\
\text { encoding the regulator of serotonin } \\
\text { receptors p11, the astrocytic } \\
\text { marker S100ß1 and the transcrip- } \\
\text { tion factor Hes534 in the } \\
\text { hippocampus of animals subjected } \\
\text { to the open-space FST } \\
\text { compared with vehicle-treated } \\
\text { animals; } \downarrow \text { expression of PDE4D } \\
\text { and NOS1 both at } \\
\text { the mRNA and protein levels in the } \\
\text { hippocampus of animals } \\
\text { subjected to the open-space FST } \\
\text { compared with vehicle-treated } \\
\text { animals. }\end{array}$ & [174] \\
\hline $\begin{array}{l}\text { Lactate (during } \\
\text { experimental } \\
\text { stress period) } \\
\text { or lactate }+\mathrm{Cl}- \\
994 \text { (after ex- } \\
\text { perimental } \\
\text { stress period) }\end{array}$ & $\begin{array}{c}\text { male } \mathrm{C} 57 \mathrm{Bl} / 6 \\
\text { mice }(8-10 \\
\text { weeks) }\end{array}$ & CSDS & $\begin{array}{l}\text { Before the estab- } \\
\text { lihsment of depres- } \\
\text { sion: Reverses social } \\
\text { avoidance and anxie- } \\
\text { ty. After the estab- } \\
\text { lihsment of depres- } \\
\text { sion: reduced depres- } \\
\text { sion-like behavior }\end{array}$ & $\begin{array}{l}\text { Before the establihsment of de- } \\
\text { pression: Restores hippocampal } \\
\text { class I HDAC2/3 levels and activity. } \\
\text { After the establihsment of depres- } \\
\text { sion: hippocampal class II HDAC5 } \\
\text { deactivation }\end{array}$ & [173] \\
\hline
\end{tabular}

Arc: Activity-Regulated Cytoskeleton-Associated Protein; COX-2: Cyclooxygenase 2; CREB: Camp Response Element-Binding Protein; CSDS: Chronic Social Defeat Stress; FST: Forced-Swim Test; GSK3 $\alpha / \boldsymbol{\beta}$ : Glycogen synthase kinase 3 alpha/beta; HDAC2/3/5: Histone Deacetylase 2/3/5; NOS1: Nitric Oxide Synthase 1; PDE4D: Camp-Specific 3',5'-Cyclic Phosphodiesterase 4D; TST: Tail Suspention Test. 
interesting study by Karnib et al. (2019) revealed that lactate has both protective and reversing effects against depression, and that these processes occur via distinct epigenetic mechanisms on HDACs [173]. In this experiment, chronic lactate administration immediately before a 10-day social defeat challenge protected against the resulting social avoidance and anxiety behaviors observed in control mice. Lactate-treated mice exhibited increased levels and activity of the class I HDAC2/3 in the hippocampus [173]. In a second group of mice, which were not given lactate during the social stress challenge period, and that exhibited depressive-like symptoms, lactate had an antidepressant effect as shown by the rescue of social avoidance behavior. After the establishment of depression, the effect of lactate was not mediated by HDAC2/3; instead, it was mediated by a reduction in HDAC5 levels [173].

Carrard et al. (2018) also demonstrated the antidepressant effect of acute and chronic intraperitoneal injections of L-lactate in a corticosterone mouse model of depression. These behavioral effects followed an increase in the hippocampal concentrations of L-lactate, and were dependent on changes in the expression of several genes implicated in the pathophysiology of depression: GSK- $\alpha$, GSK- $\beta$ and CREB phosphorylation levels were significantly decreased, while the expression of Arc was increased and COX-2 and NOS1 decreased [174]. In addition to changes in the expression of depression-related or plasticity-related genes (GSK- $\alpha$, GSK- $\beta$, CREB, Arc, COX- 2 and NOS1), the behavioral effects of lactate were mediated by an increase in hippocampal p11 (regulator of 5-HT receptors), S100 $\beta$ (astrocytic marker), Hes5 (transcription vector) and a decrease in cAMPspecific phosphodiesterase-4D (PDE4D) and NOS1 mRNA and protein levels [174].

Since lactate can also be synthetized by astrocytes on neuronal demand as a byproduct of glycolysis [175], it remains difficult to assess the net effect of microbial metabolism on central levels of lactate and mood. A simple way to isolate the contribution of the gut microbiome in the relationship between lactate production and depressive behavior would be using germ-free rodents; to the best of our knowledge, this has not been investigated to date. However, the well-established interchange of lactate between the periphery and the CNS [163] points towards a role of the gut microbiota in mediating the antidepressant effects of lactate. In support of this statement, the beneficial effects of exercise on mood have been hypothesized to be due to gut microbiota-mediated changes in the production of lactate $[176,177]$.

\section{Bile acids}

Bile acids are cholesterol-derived steroid acids synthesized in the liver, secreted into the small intestine and absorbed in the ileum. The two primary bile acids (in humans and rats), cholic acid (CA) and chenodeoxycholic acid (CDCA), undergo further structural modifications in the gut by means of the gut microbiota, which convert them into secondary and tertiary bile acids [178]. Bile acids have local detergent properties that enables them to emulsify lipophilic molecules and, in turn, facilitate nutrient digestion and absorption. However, they can also act as signaling molecules to modulate feeding behavior and in turn, control glucose homeostasis, lipid metabolism and energy expenditure [179]. Their signaling pathways are initiated by their binding to the farnesoid $X$ receptor (FXR) and the Takeda G protein-coupled receptor 5 (TGR5) [180].

The FXR is a nuclear receptor that is involved in the synthesis, secretion and transport of bile acids [181], as well as in the modulation of CREB activity [182]. Through its inhibitory control of the transcription factor CREB, bile acids can repress the transcription of several genes, including BDNF. Since the first reports of FXR expression in the brain [180, 183], the possibility has been explored that BDNF abnormalities found in the brains of depressed individuals may be accounted for, in part, by altered bile acid activity. Supportive of this hypothesis, the chronic unpredictable mild stress (CUMS) rodent model of depression exhibits enhanced hippocampal FXR expression, and in turn, FXR overexpression in the rat hippocampus is sufficient to induce depressive-like behavior in naïve animals [184]. These behavioral changes were mirrored by a significant decrease in BDNF expression in the hippocampus of rats overexpressing FXR. In contrast, FXR knockdown in naïve rats had a strong antidepressant effect as measured by the forced-swim and tail suspension tests, and prevented the occurrence of CUMS-associated behavioral (depressive-like symptoms) and molecular (decreased BDNF expression) abnormalities [184]. The antidepressant effect of FXR genetic deletion was confirmed in an independent study, which also reported altered glutamatergic, GABAergic, serotonergic, and noradrenergic neurotransmission in the hippocampus and cerebellum of FXR knockout mice, while no change was detected in the prefrontal cortex [185]. Deletion of FXR also led to disrupted bile acid metabolism and to increased bile acid abundance both peripherally and centrally $[185,186]$. Different rodent models of depression have reported increased abundance of bile acids in urine and plasma [187], as well as in the fecal metabolic phenotype [188]. Su et al. [189], instead, reported an upregulation in serum glycocholic acid, but a decrease in cholic acid in chronic variable stress (CVS)-induced depression rats. These abnormalities were associated with a reduced abundance of Peptostreptococcaceae incertaesedis [188], supporting a link with altered microbiota function.

Moreover, bile acids may contribute to major depression by disrupting tight junction expression, leading to permeabilization of both intestinal and central epithelial cells [190]. Chenodeoxycholic acid or deoxycholic acid injections permealized the BBB in naïve rats [190]. When investigated in rat brain microvascular endothelial cells, increased BBB permeability upon administration of chenodeoxycholic acid or deoxycholic acid was found to be mediated by occludin phosphorylation in a Rac-1dependent and FXR-independent fashion [190]. Enhanced permeabilization of intestinal epithelial barrier in human Caco-2 monolayers was associated with phosphorylation of the epithelial growth factor (EGF) receptor and dephosphorylation of the tight junction occludin. This occurred in response to administration of the hydrophobic 
TABLE 6. Studies investigating the effects of bile acids on depressive-like behavior.

\begin{tabular}{|c|c|c|c|c|c|}
\hline Treatment & $\begin{array}{c}\text { Species or } \\
\text { strain }\end{array}$ & Model & Behavioral outcomes & Molecular mechanisms & Reference \\
\hline $\begin{array}{l}\text { FXR knockout } \\
\text { mice }\end{array}$ & $\begin{array}{l}\text { C57BL/6 (4-5 } \\
\text { months) }\end{array}$ & - & $\begin{array}{l}\downarrow \text { immobility time in } \\
\text { TST but not in FST (im- } \\
\text { proved depressive-like } \\
\text { symptoms); } \uparrow \text { motor } \\
\text { activity; impaired } \\
\text { memory. }\end{array}$ & $\begin{array}{l}\downarrow \text { hippocampal GAD65 and } \uparrow \text { cere- } \\
\text { bral GAT1; changes in bile acid con- } \\
\text { centrations in serum (taurodehydro- } \\
\text { cholic acid, taurocholic acid, deoxy- } \\
\text { cholic acid, glycocholic acid, tauro- } \alpha \text { - } \\
\text { muricholic acid, tauro- } \omega \text {-muricholic } \\
\text { acid, and hyodeoxycholic acid) and } \\
\text { brain (taurocholic acid, taurodehy- } \\
\text { drocholic acid, tauro- } \omega \text {-muricholic } \\
\text { acid, tauro- } \beta \text {-muricholic acid, deoxy- } \\
\text { cholic acid, and lithocholic acid) }\end{array}$ & [185] \\
\hline $\begin{array}{l}\text { FXR overexpres- } \\
\text { sion (LV-FXR- } \\
\text { EGFP) }\end{array}$ & $\begin{array}{l}\text { Male Spra- } \\
\text { gue-Dawley } \\
\text { rats (7 weeks) }\end{array}$ & - & $\begin{array}{c}\text { Exacerbates depres- } \\
\text { sive-like behavior in } \\
\text { the FST, TST and SPT in } \\
\text { naïve rats }\end{array}$ & $\begin{array}{l}\text { No change in hippocampal expres- } \\
\text { sion of CREB and CRTC2; } \downarrow \text { expres- } \\
\text { sion of BDNF in hippocampus. }\end{array}$ & [184] \\
\hline $\begin{array}{c}\text { FXR knockdown } \\
\text { (LV-FXR-shRNA- } \\
\text { EGFP) } \\
\end{array}$ & $\begin{array}{l}\text { Male Spra- } \\
\text { gue-Dawley } \\
\text { rats ( } 7 \text { weeks) }\end{array}$ & CUMS & $\begin{array}{l}\text { Prevents depressive- } \\
\text { like behavior in the } \\
\text { FST, TST and SPT. }\end{array}$ & $\begin{array}{l}\text { Restores decrease in hippocampal } \\
\text { BDNF expression. }\end{array}$ & [184] \\
\hline $\begin{array}{l}\text { Chronic TUDCA } \\
\text { (100, } 200 \mathrm{mg} / \mathrm{kg} \text {; } \\
\text { ip) or fluoxetine } \\
\text { (20 mg/kg; ip) or } \\
\text { TUDCA + fluoxe- } \\
\text { tine co-treatment } \\
\text { for } 10 \text { days }\end{array}$ & $\begin{array}{c}\text { Male } \\
\text { C57BL/6J } \\
\text { mice (8-10 } \\
\text { weeks) }\end{array}$ & CUS & $\begin{array}{l}\text { TUDCA (at } 200 \mathrm{mg} / \mathrm{kg} \text { ) } \\
\downarrow \text { immobile time in TS } \\
\text { and FST; } \uparrow \text { crossing } \\
\text { numbers in the OFT; } \uparrow \\
\text { sucrose intake in SPT } \\
\text { compared to vehicle }\end{array}$ & $\begin{array}{c}\text { TUDCA (at } 200 \mathrm{mg} / \mathrm{kg} \text { ) } \downarrow \text { TNF } \alpha \text { and } \\
\text { IL-6 in hippocampus and PFC }\end{array}$ & [192] \\
\hline
\end{tabular}

BDNF: Brain-Derived Neurotrophic Factor; CREB: Camp Response Element-Binding Protein; CRTC2: CREB-Regulated Transcription Coactivator 2; CUMS: Chronic Unpredictable Mild Stress; CUS: Chronic Unpredictable Stress; FST: Forced-Swim Test; FXR: Farnesoid X Receptor; GAD65: Glutamic Acid Decarboxylase 65; GAT1: GABA Transporter 1; IL-6: Interleukin-6; OFT: Open Field Test; SPT: Sucrose Preference Test; Tnfa: Tumor Necrosis Factor Alpha; TST: Tail Suspension Test; TUDCA: Tauroursodeoxycholic Acid.

bile acids cholic acid, chenodeoxycholic acid and deoxycholic acid, but not the hydrophilic bile acid ursodeoxycholic acid [191]. These findings suggest that the effect of bile acids may be to some extent dependent on their chemical and physical properties, which in turn, relies upon microbial-mediated modification of these compounds.

Another factor that may influence the behavioral outcome of bile acids is the receptor that mediates the response (Table 6). Binding of the TGR5 receptor by the secondary bile acid tauroursodeoxycholic acid (TUDCA) ameliorates the depressive phenotype of CUS mice by dampening neuroinflammation (TNF- $\alpha$ and IL-6), as well as oxido-nitrosative and endoplasmic reticulum stress [192]. This is consistent with previous reports of the neuroprotective effects of TUDCA in microglia [193]. Additionally, some bile acids, like lithocholic acid can stimulate central PXR and vitamin D receptor (VDR) [194], which have wellestablished antidepressant effects $[195,196]$. Thus, the impact of bile acids on depressive behavior may be dependent on the specific receptor that they act upon, with FXR mediating pro-depressive phenotype, and PXR, VDR and TGR5 mediating their antidepressant action. This hypothesis has yet to be formally tested.

\section{Choline metabolites}

Choline is an essential nutrient mainly obtained from dietary lecithin and carnitine, but in humans, small amounts of choline can also be synthesized in the liver [197]. Choline has structural, epigenetic and cell signaling functions. It is involved in the synthesis of acetylcholine and it is a precursor of the cell membrane components phosphatidylcholine and sphingomyelin. Although not a bacterial product per se, choline is broken down by the action the gut microbiota into a range of metabolites, including trimethylglycine (betaine) and trimethylamine (TMA). In the liver, flavin monooxygenase, a family of xenobiotic-metabolizing enzymes, can further convert TMA into trimethylamine- $N$ oxide (TMAO) [198]. The role of the gut microbiota in choline metabolism is demonstrated by the positive association found between the plasma levels of TMA and TMAO with the microbial order Clostridiales, the genus Ruminococcus, and the taxon Lachnospiraceae, and the negative association with proportions of S24-7, an abundant family from Bacteroidetes, in mice [199]. In a CUMS rat model, depression was associated with increased TMA but decreased TMAO levels [200]. Since choline metabolism by the gut microbiota can deplete choline stores available for the host, excessive choline-utilizing bacteria can mimic the effects of choline deficiency, such as increased occurrence 
TABLE 7. Studies investigating the effects of choline metabolites on depressive-like behavior.

\begin{tabular}{|c|c|c|c|c|c|}
\hline Treatment & $\begin{array}{l}\text { Species or } \\
\text { strain }\end{array}$ & Model & $\begin{array}{l}\text { Behavioral out- } \\
\text { comes }\end{array}$ & Molecular mechanisms & Reference \\
\hline $\begin{array}{l}\text { Methyl donor } \\
\text { supplementation } \\
\text { (choline, betaine, } \\
\text { folate, vitamin } \\
\text { B12) for } 18 \text { weeks }\end{array}$ & Wistar rats & $\begin{array}{l}\text { ELS (maternal } \\
\text { separation) }\end{array}$ & $\begin{array}{c}\downarrow \text { depressive be- } \\
\text { havior in the Porsolt } \\
\text { FST }\end{array}$ & $\begin{array}{l}\text { normalisation of total and } \\
\text { HDL-cholesterol; } \uparrow \text { total DNA } \\
\text { methylation and } \\
\text { 个hippocampal (not hypotha- } \\
\text { lamic) expression of the insu- } \\
\text { lin receptor }\end{array}$ & {$[213\}$} \\
\hline
\end{tabular}

HDL: High-Density Lipoprotein; FST: Forced Swim Test.

of metabolic diseases, higher cardiovascular risk, as well as altered behavior [201]. For example, reduced choline availability in the hippocampus and basal ganglia was reported in MDD patients [202, 203]. Reduced circulatory choline $[117,204]$, but elevated plasma TMAO [204] were also found in patients with depressive symptoms. However, this evidence is far from conclusive, as increased central concentrations of choline have been reported in depressed adults $[195,205,206]$ as well as children and adolescents [207-209]. Moreover, the choline metabolites dimethylamine, dimethylglycine, and TMAO were found to be significantly lower in the urine of MDD subject compared to controls [210]. It is apparent that contradictory evidence exists with regards to the role of these microbial metabolites in the context of depression. The finding that urinary choline concentrations were lower in moderate MDD, but higher in severe MDD compared to matched control [211] hints to the complexity of choline metabolism in relation to depressive behavior.

Thus, different mechanisms may exist through which choline and its metabolites influence emotional behavior. One of these potential modes of action is DNA methylation. Romano et al. [201] showed that bacterial consumption of choline reduced the availability of methyl donors and altered global DNA methylation patterns in both the adult mice and their offspring, in line with previous reports of maternal choline deficiency inducing diminished hippocampal DNA methylation and neurodevelopmental abnormalities in the offspring [212]. Choline contributes to DNA methylation by modulating the production of the methyl donor S-adenosylmethionine (SAM) [201]. In a rat model of early-life stress, supplementation of choline and betaine and other methyl donors was successful in reversing depressive-like behavior [213]. In humans, betaine exhibited a positive effect on mood by promoting the DNA methylation of SAM: in subjects with mild MDD, adjunctive treatment of SAM with betaine showed higher antidepressant efficacy than treatment with SAM alone [214].

An alternative mechanism involves the modulation of neurotransmission. Oral ingestion of choline increases its concentrations in the brain [215], suggesting that dietary choline can contribute to acetylcholine synthesis. This suggests that abnormal choline metabolism may promote depressive behavior by altering the availability of choline destined for acetylcholine synthesis. In fact, the neurotransmitter acetylcholine is present in significantly higher concentrations in MDD patients than in healthy subjects [216]. Since choline can reach the CNS via active transport across the BBB [217], excessive choline in the periphery may have a significant impact on mood and behavior.

There remains uncertainty regarding the impact of choline metabolites on behavior (Table 7). While choline deficiency may be detrimental for mental health due to insufficient DNA methylation, excessive choline may contribute to depressive pathology by leading to enhanced acetylcholine synthesis. In addition, the extent to which the gut microbiota impacts on choline metabolism remains unknown, since clinical trials have shown that TMAO levels do not respond to prebiotic administration [218-220].

\section{Vitamins (folate)}

Most bacteria in the gut, such as Lactobacillus and Bifidobacterium, synthesize vitamins (particularly B-group vitamins and vitamin $\mathrm{K}$ ) as part of their metabolic processes in the large intestine, and humans rely heavily on the gut microbiota for their production [221]. Vitamins are essential micronutrients with ubiquitous roles in a great number of physiological processes in several organs in the human body, including the brain. Fat-soluble vitamins (such as vitamins $A, D, E$, and $K$ ) make up the cell membrane, while water-soluble vitamins (including the vitamin B family and vitamin C) are enzymatic co-factors for a wide number of physiological reactions [221]. Active transporters are responsible for their transport across the BBB [222]. In the CNS, their role extends from energy homeostasis to neurotransmitter production [223], meaning that vitamin deficiencies can have a significant negative impact on neurological function (e.g. neural tube defects during fetal development). Folic acid, or vitamin B9, is a vitamin of microbial origin that has been extensively implicated in the pathology of depression (Table 8), with one third of depressed patients exhibiting a folate deficiency [224]. Its biosynthesis by the gut microbiota requires the $\mathrm{C}-\mathrm{N}$ binding of 6-hydroxymethyl-7,8-dihydropterin pyrophosphate (DHPPP) - obtained from guanosine triphosphate (GTP) and $p$-aminobenzoic acid (pABA) - a product of the pentose phosphate pathway [225]. 
TABLE 8. Studies investigating the effects of folate on depressive-like behavior.

\begin{tabular}{|c|c|c|c|c|c|}
\hline Treatment & Species or strain & Model & Behavioral outcomes & $\begin{array}{l}\text { Molecular mecha- } \\
\text { nisms }\end{array}$ & Reference \\
\hline Folic acid (75 mg/kg) & $\begin{array}{l}\text { Male Sprague- } \\
\text { Dawley rats }\end{array}$ & CUMS & $\begin{array}{l}\text { Improvement of depression-like } \\
\text { behaviors as assessed in FST, TST } \\
\text { and OFT }\end{array}$ & $\begin{array}{l}\text { 个5-HT, BDNF and } \\
\text { GluR1 expression; } \\
\text { changes in synaptic } \\
\text { organisation in the } \\
\text { brain }\end{array}$ & [227] \\
\hline $\begin{array}{l}\text { Folic acid (p.o. and i.c.v.) } \\
+ \text { PCPA (100 mg/kg) or } \\
\text { fluoxetine }(10 \mathrm{mg} / \mathrm{kg} \text {, } \\
\text { p.o.) or WAY100635 (0.1 } \\
\mathrm{mg} / \mathrm{kg} \text {, s.c.) or ketanserin } \\
\text { (5 mg/kg) or yohimbine } \\
\text { (1 mg/kg, i.p.) }\end{array}$ & $\begin{array}{l}\text { Male and female } \\
\text { Swiss mice }\end{array}$ & - & $\begin{array}{l}\downarrow \text { immobility time in the FST; no } \\
\text { effect on locomotor activity; } \\
\text { PCPA blocked the decrease in } \\
\text { immobility time elicited by folic } \\
\text { acid; co-administration of a su- } \\
\text { beffective fluoxetine produced a } \\
\text { synergistic effect with a subeffec- } \\
\text { tive dose of folic acid; } \\
\text { WAY100635 significantly blocked } \\
\text { the decrease in immobility time } \\
\text { in the FST elicited by full dose of } \\
\text { folic acid; WAY100635 produced } \\
\text { a synergistic effect with a su- } \\
\text { beffective dose of folic acid; } \\
\text { ketanserin blocked the decrease } \\
\text { in immobility time in the FST } \\
\text { elicited by folic acid; yohimbine } \\
\text { was also able to prevent the anti- } \\
\text { immobility effect the folic acid }\end{array}$ & (1) & {$[226]$} \\
\hline $\begin{array}{c}\text { folic acid (10 nmol/site, } \\
\text { i.c.v.) + naloxone (1 } \\
\text { mg/kg, i.p.) or naltrindole } \\
\text { ( } 3 \mathrm{mg} / \mathrm{kg} \text {, i.p.) or nalox- } \\
\text { onazine (10 mg/kg, i.p.) } \\
\text { or naloxone methiodide } \\
\quad(1 \mathrm{mg} / \mathrm{kg} \text {, s.c.) }\end{array}$ & $\begin{array}{l}\text { Male and female } \\
\text { Swiss mice }\end{array}$ & - & $\begin{array}{l}\text { Naloxone, naltrindole, naloxon- } \\
\text { azine, but not naloxone methio- } \\
\text { dide, prevented the antidepres- } \\
\text { sant-like effect of folic acid in the } \\
\text { FST; folic acid + morphine had a } \\
\text { synergistic anti-depressant effect } \\
\text { in the FST (but no effect on lo- } \\
\text { comotion); naloxone reversed } \\
\text { the anti-depressant properties of } \\
\text { folic acid + MK-801 }\end{array}$ & - & [232] \\
\hline $\begin{array}{l}\text { Folate-depleted vs folate- } \\
\text { supplemented diets }\end{array}$ & $\begin{array}{l}\text { Adult male and } \\
\text { female Wistar } \\
\text { Kyoto rats }\end{array}$ & $\begin{array}{l}\text { ELS (maternal } \\
\text { separation) }\end{array}$ & $\begin{array}{c}\text { dietary methyl donor supplemen- } \\
\text { tation induced } \uparrow \text { exploratory } \\
\text { behavior in the OFT, exhibit } \\
\uparrow \text { social behavior and } \downarrow \text { immo- } \\
\text { bile time in the FST }\end{array}$ & $\begin{array}{l}\text { } \text { PDA methylation in } \\
\text { the hippocampus of } \\
\text { mice exposed to ma- } \\
\text { ternal separation; } \\
\text { 个brain methionine } \\
\text { levels in rats supple- } \\
\text { mented with methyl } \\
\text { donors }\end{array}$ & [234] \\
\hline $\begin{array}{l}\text { Methyl donor supple- } \\
\text { mentation (choline, beta- } \\
\text { ine, folate, vitamin B12) } \\
\text { for } 18 \text { weeks }\end{array}$ & Wistar rats & $\begin{array}{l}\text { ELS (maternal } \\
\text { separation) }\end{array}$ & $\begin{array}{c}\downarrow \text { depressive behavior in the } \\
\text { Porsolt FST }\end{array}$ & $\begin{array}{c}\text { normalisation of total } \\
\text { and HDL-cholesterol; } \\
\text { 个total DNA methyla- } \\
\text { tion and } \\
\text { 个hippocampal (not } \\
\text { hypothalamic) expres- } \\
\text { sion of the insulin } \\
\text { receptor } \\
\end{array}$ & [213] \\
\hline $\begin{array}{c}\text { Folic acid (5 or } 10 \\
\text { nmol/i.c.v.; } 25,50 \text { or } 75 \\
\mathrm{mg} / \mathrm{kg} \text { p.o.), or fluoxetine } \\
\text { ( } 20 \text { or } 25 \mathrm{mg} / \mathrm{kg} \text { ) or } 17-\beta \\
\text { estradiol }(10 \text { or } 20 \\
\mu \mathrm{g} / \mathrm{rat}) ; \text { combination of } \\
\text { folic acid }(2.5 \mathrm{nmol} / \mathrm{i} . c . v . ; \\
\text { or } 25.0 \mathrm{mg} / \mathrm{kg}, \text { p.o. })+ \\
\text { fluoxetine }(15.0 \mathrm{mg} / \mathrm{kg}) ; \\
\text { combination of folic acid } \\
(2.5 \mathrm{nmol} / \mathrm{i} . c . v . ; \text { or } 25.0 \\
\mathrm{mg} / \mathrm{kg}, \mathrm{p.o.})+17-\beta \text { estra- } \\
\text { diol }(5 \mu \mathrm{gg} / \mathrm{rat})\end{array}$ & $\begin{array}{l}\text { Female Wistar } \\
\text { rats }\end{array}$ & ovariectomized & $\begin{array}{l}\downarrow \text { immobility in the FST; antide- } \\
\text { pressant effects were not } \\
\text { achieved if ketanserin was ad- } \\
\text { mnistered. }\end{array}$ & (2) & [228] \\
\hline
\end{tabular}

5-HT: 5-Hydroxytryptamine; BDNF: Brain-Derived Neurotrophic Factor; CUMS: Chronic Unpredictable Mild Stress; ELS: Early-Life Stres; FST: Forced-Swim Test; GluR1: Glutamate Receptor 1; HDL: High-Density Lipoprotein; MK-801: Non-Competitive NMDA Receptor Antagonist; OFT: Open Field Test; PCPA: Para-Chlorophenylalanine; TST: Tail Suspension Test; WAY100635: 5- $\mathrm{HT}_{1} \mathrm{~A}$ Receptor Antagonist And Full $\mathrm{D}_{4}$ Receptor Agonist. 
Folate has an established antidepressant effect in animal models of depression [226-228], with some clinical studies suggesting its potential as antidepressant augmentation therapy in humans $[229,230]$. Using a series of pharmacological inhibitors, Brocardo et al. [226] showed that the antidepressant effects of folic acid were dependent of serotonergic (5- $\mathrm{HT}_{1 \mathrm{~A}}$ and $5-\mathrm{HT}_{2 \mathrm{~A} / 2 \mathrm{C}}$ receptors) and noradrenergic ( $\alpha 1$ - and $\alpha 2$-adrenoceptors) activity in mice. The finding that serotonergic and noradrenergic antagonists prevented the antidepressant effects of folic acid supports the possibility that a mechanism of action is represented by an enhancement of monoaminergic production. Folic acid can synthesize tetrahydrobiopterin (BH4), which in turns act as a cofactor for the conversion of phenylalanine and tryptophan into the neurotransmitters dopamine, norepinephrine, and 5-HT [231]. With a similar design, the same group demonstrated that the antidepressant action of folic acid was mediated by the opioid system, as treatment of the mice with different opioid receptor antagonists prevented the folate-induced reduction in immobility time in the forced swim test [232]. The authors also proposed that the action of folic acid may involve inhibition of NMDA receptors [232].

In addition to increased central 5-HT concentrations, folic acid can also induce an increase in BDNF and GluR1 expression in the hippocampus and association cortex, concurrent with a normalization in serum corticosterone concentration, mitochondria structure and spine synapse numbers that were altered in the CUMS model of depression [227]. Due to its involvement in the synthesis of DNA, RNA and proteins and in DNA methylation reactions [233], folate may exert these changes via epigenetics mechanisms. A diet rich in methyl donors such as folic acid has beneficial effects on exploratory behavior, social interaction and depressive-like behavior in rats $[213,234]$. The active metabolite of folate, 5-methyltetrahydrofolate (5-MTHF), converts homocysteine into methionine, which is used for the production of the methyl group donor SAM. In turn, SAM has been demonstrated to have antidepressant properties [235] via DNA methylation of phospholipids $[236,237]$, with extensive consequences on neurotransmission [238]. Despite the marked improvement in depressive behavior obtained in animal studies, clinical trials have highlighted great heterogeneity and do not provide strong evidence on the benefits of the use of folate as and adjunctive strategy for depression [239].

\section{FUTURE DIRECTIONS}

Almost one third of depressed patients do not respond to treatment long-term [240]. The known impact of the microbiome on pathways involved in depression, as well as evidence linking abnormal microbiota and depressive behavior [14], suggest that targeting the gut microbiota may be an attractive strategy to improve depression-related pathological features. A strong advantage of this approach is the accessibility of the microbiome to nutritional modulation. In fact, administration of the probiotics Bifidobacterium infantis, Lactobacillus rhamnosus, Lactobacillus hel- veticus R0052 and Bifidobacterium longum R0175 have proved effective in normalizing the gut microbiome and alleviating anxiety- and depression-like symptoms in both rodents [55, 58] and healthy humans [241].

However, the complexity of the microbiota and its biochemical exchange with the host need to be better understood before this trans-kingdom communication can be harnessed to ameliorate neurological disorders. The contradictory findings reported across several studies may be reflective of this complexity. Components of the gut microbiota are in a dynamic state of equilibrium, dependent on substrate availability, exposure to antimicrobial compounds and competition with other bacterial strains. In vitro, the production of neuroactive metabolites by probiotics can be affected by nutrient availability [61]. Similarly, an intricate interplay exists between human and bacterial metabolism, as well as among the metabolic pathways reviewed. For example, intestinal neurotransmitter production is intrinsically linked to the abundance of SCFAs and bile acids in the gut, and inflammatory molecules like nitrate promote metabolism of choline by choline-utilizing bacteria [242], suggesting that the psychotropic effect of a specific metabolite may be tightly dependent on the presence of other metabolites. Another challenge encountered by gut-brain axis research is the ability to discriminate between peripheral production of neuroactive metabolites by the gut microbiota, and host production of the same metabolites in the brain. This makes it challenging to understand the extent to which the observed effect on depressive behavior can be ascribed to gut microbial metabolism per se (as compared to host central metabolism).

\section{CONCLUSION}

MDD is a multifaceted mental disorder characterized by a dysfunction of neurochemical, neuroendocrine, immune and metabolic systems. The microbiota-gut-brain axis is a bidirectional network linking the central and enteric nervous systems through the same neural, immune and metabolic routes that are dysregulated in depression [243, 244]. Therefore, gut-brain axis abnormalities in depressed patients may, at least partly, account for the symptomatic presentations of depression. This review highlights how metabolites modulated by the intestinal microbiota can influence mood through their direct action on central receptors, through activation of peripheral receptors on neural, immune or neuroendocrine pathways, and through epigenetic regulation of histone deacetylation or DNA methylation (Table 9).

Addressing knowledge gaps on the multifactorial interplay between products of microbial metabolism in relation to their antidepressant effects will advance our understanding of the pathological mechanisms of depression (via the gut-brain axis) and may facilitate the development of more refined pharmacological strategies. 
TABLE 9. Effects of microbial metabolites on depressive behavior in rodent and human studies.

\begin{tabular}{|c|c|c|c|c|c|c|}
\hline $\begin{array}{l}\text { Microbial } \\
\text { metabolite }\end{array}$ & Family & $\begin{array}{l}\text { Metabolic } \\
\text { pathway }\end{array}$ & Metabolising bacteria & $\begin{array}{l}\text { Effects on help- } \\
\text { lessness (rodent } \\
\text { studies) }\end{array}$ & $\begin{array}{l}\text { Effects on } \\
\text { mood (human } \\
\text { studies) }\end{array}$ & $\begin{array}{l}\text { Potential } \\
\text { mechanisms }\end{array}$ \\
\hline Propionate & \multirow{3}{*}{ SCFA } & \multirow{3}{*}{$\begin{array}{l}\text { Fermentation } \\
\text { of fibres / } \\
\text { carbohydrate } \\
\text { metabolism }\end{array}$} & $\begin{array}{l}\text { Roseburia, Ruminococcus, } \\
\text { Salmonella, Blautia, Phasco- } \\
\text { larctobacterium, Dialister, } \\
\text { Coprococcus, Megasphaera }\end{array}$ & $\begin{array}{l}\text { Improves de- } \\
\text { pressed mood }\end{array}$ & \multirow{3}{*}{$\begin{array}{l}\text { Depleted in } \\
\text { MDD patients }\end{array}$} & \multirow{3}{*}{$\begin{array}{l}\text { Epigenetics } \\
\text { (HDACi and } \\
\text { DNA methyla- } \\
\text { tion modula- } \\
\text { tor); receptors } \\
\text { (GPR43, } \\
\text { GPR41) }\end{array}$} \\
\hline Acetate & & & Blautia, Marvinbryantia & - & & \\
\hline Butyrate & & & $\begin{array}{c}\text { Eubacterium, Roseburia, } \\
\text { Anaerostipes, Coprococcus, } \\
\text { Feacalibacterium }\end{array}$ & $\begin{array}{l}\text { Improves de- } \\
\text { pressed mood; } \\
\text { augments the } \\
\text { effect of antide- } \\
\text { pressant drugs }\end{array}$ & & \\
\hline GABA & \multirow{4}{*}{ NT } & & Lactobacillus, Bifidobacterium & $\begin{array}{c}\text { Antidepressant } \\
\text { effect }\end{array}$ & $\begin{array}{l}\text { Depleted in } \\
\text { MDD patients }\end{array}$ & \\
\hline Serotonin & & & $\begin{array}{c}\text { Escherichia coli, Streptococcus, } \\
\text { Enterococcus, Akkermansia, } \\
\text { Alistipes, Roseburia }\end{array}$ & $\begin{array}{c}\text { Antidepressant } \\
\text { effect }\end{array}$ & $\begin{array}{l}\text { Depleted in } \\
\text { MDD patients }\end{array}$ & \\
\hline Dopamine & & & $\begin{array}{l}\text { Escherichia coli, Bacillus cere- } \\
\text { us, Bacillus mycoides, Bacillus } \\
\text { subtilis, Proteus vulgaris, Ser- } \\
\text { ratia marcescens and Staphy- } \\
\text { lococcus aureus }\end{array}$ & $\begin{array}{c}\text { Antidepressant } \\
\text { effect }\end{array}$ & $\begin{array}{l}\text { Depleted in } \\
\text { MDD patients }\end{array}$ & \\
\hline Acetylcholine & & & Lactobacillus & - & $\begin{array}{l}\text { Increased in } \\
\text { MDD patients }\end{array}$ & \\
\hline Oxindole & & & & Neurodepressant; & - & \multirow{3}{*}{$\begin{array}{c}\text { Epigenetics } \\
\text { (HDACi); mod- } \\
\text { ulation of } \\
\text { tryptophan } \\
\text { availability; } \\
\text { receptor AhR } \\
\text { receptors (FXR } \\
\text { and TGR5, PXR } \\
\text { and VDR) }\end{array}$} \\
\hline Isatin & Indoles & $\begin{array}{l}\text { Tryptophan } \\
\text { metabolism }\end{array}$ & $\begin{array}{c}\text { Escherichia coli, Vibrio chol- } \\
\text { erae and many others }\end{array}$ & $\begin{array}{l}\text { Anxiogenic and } \\
\text { pro-depressive; }\end{array}$ & 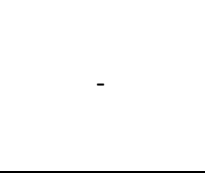 & \\
\hline $\begin{array}{l}\text { Deoxycholic } \\
\text { acid }\end{array}$ & Bile acids & $\begin{array}{l}\text { Primary bile } \\
\text { acid conjuga- } \\
\text { tion }\end{array}$ & $\begin{array}{c}\text { Lactobacillus, Enterococcus, } \\
\text { Bacteroides, Clostridium }\end{array}$ & $\begin{array}{l}\text { permealization of } \\
\text { the BBB }\end{array}$ & $\begin{array}{l}\text { permealization } \\
\text { of intestinal } \\
\text { barrier (Caco-2 } \\
\text { monolayer) } \\
\end{array}$ & \\
\hline $\begin{array}{l}\text { Glycocholic } \\
\text { acid }\end{array}$ & & & & $\begin{array}{l}\text { increased in se- } \\
\text { rum of depression } \\
\text { model }\end{array}$ & 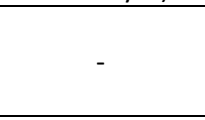 & $\begin{array}{c}\text { receptors (FXR } \\
\text { and TGR5, PXR } \\
\text { and VDR) }\end{array}$ \\
\hline TUDCA & & & & $\begin{array}{l}\text { neuroprotective } \\
\text { against microglia }\end{array}$ & - & $\begin{array}{c}\text { receptors (FXR } \\
\text { and TGR5, PXR } \\
\text { and VDR) }\end{array}$ \\
\hline $\begin{array}{l}\text { Taurocholic } \\
\text { acid }\end{array}$ & & & & $\begin{array}{l}\text { FXR overexpres- } \\
\text { sion in the rat } \\
\text { hippocampus is } \\
\text { sufficient to in- } \\
\text { duce depressive- } \\
\text { like behavior, } \\
\text { while FXR knock- } \\
\text { down is both pro- } \\
\text { tective and revers- } \\
\text { ing again depres- } \\
\text { sive-like behavior; } \\
\text { increased abun- } \\
\text { dance of bile acids } \\
\text { in urine, plasma } \\
\text { and faecesof de- } \\
\text { pression models }\end{array}$ & - & $\begin{array}{l}\text { receptors (FXR } \\
\text { and TGR5, PXR } \\
\text { and VDR) }\end{array}$ \\
\hline
\end{tabular}


TABLE 9 (continued). Effects of microbial metabolites on depressive behavior in rodent and human studies.

\begin{tabular}{|c|c|c|c|c|c|c|}
\hline $\begin{array}{l}\text { Microbial } \\
\text { metabolite }\end{array}$ & Family & $\begin{array}{l}\text { Metabolic } \\
\text { pathway }\end{array}$ & Metabolising bacteria & $\begin{array}{l}\text { Effects on helpless- } \\
\text { ness (rodent studies) }\end{array}$ & $\begin{array}{l}\text { Effects on mood } \\
\text { (human studies) }\end{array}$ & $\begin{array}{l}\text { Potential mech- } \\
\text { anisms }\end{array}$ \\
\hline Betaine & \multirow{3}{*}{$\begin{array}{l}\text { Choline } \\
\text { deriva- } \\
\text { tives }\end{array}$} & \multirow{3}{*}{$\begin{array}{l}\text { Choline } \\
\text { metabolism }\end{array}$} & \multirow{3}{*}{ Bacteroidetes } & $\begin{array}{l}\text { Reverses depressive- } \\
\text { like behavior }\end{array}$ & $\begin{array}{l}\text { Reduced in urine } \\
\text { of MDD patients; } \\
\text { ameliorates } \\
\text { symptoms of } \\
\text { depression } \\
\end{array}$ & \multirow{3}{*}{$\begin{array}{l}\text { Affects abun- } \\
\text { dance of choline } \\
\text { available for } \\
\text { DNA methyla- } \\
\text { tion and acetyl- } \\
\text { choline synthe- } \\
\text { sis }\end{array}$} \\
\hline TMA & & & & - & $\begin{array}{l}\text { Reduced in urine } \\
\text { of MDD patients }\end{array}$ & \\
\hline TMAO & & & & - & $\begin{array}{l}\text { Reduced in urine } \\
\text { but elevated in } \\
\text { plasma of MDD } \\
\text { patients }\end{array}$ & \\
\hline Lactate & - & $\begin{array}{l}\text { Carbohy- } \\
\text { drate me- } \\
\text { tabolism }\end{array}$ & $\begin{array}{l}\text { L. lactis, L. gasseri, and L. } \\
\text { reuteri, Bifidobacteria and } \\
\text { Proteobacteria, Eubacterium, } \\
\text { Anaerostipes, Veillonella }\end{array}$ & $\begin{array}{l}\text { protective and re- } \\
\text { versing effects } \\
\text { against depression }\end{array}$ & $\begin{array}{l}\text { Increased in } \\
\text { urine of MDD } \\
\text { patients }\end{array}$ & $\begin{array}{c}\text { Epigenetics } \\
\text { (HDACi and DNA } \\
\text { methylation } \\
\text { modulator); } \\
\text { receptor GPR81 } \\
\end{array}$ \\
\hline Folate (B9) & $\begin{array}{l}\text { Vita- } \\
\text { min }\end{array}$ & $\begin{array}{l}\text { GTP metab- } \\
\text { olism }\end{array}$ & $\begin{array}{c}\text { Lactobacillus (L. acidophilus, } \\
\text { L. casei, L. paracasei, L. } \\
\text { plantarum, L. reuteri, and L. } \\
\text { salivari- } \\
\text { us) and Bifidobacterium }\end{array}$ & antidepressant effect & $\begin{array}{l}\text { enhances action } \\
\text { of antidepres- } \\
\text { sant drugs (but } \\
\text { lack of conclu- } \\
\text { sive evidence) }\end{array}$ & $\begin{array}{c}\text { Epigenetics } \\
\text { (DNA methyla- } \\
\text { tion modulator); } \\
\text { serotonergic, } \\
\text { noradrenergic, } \\
\text { opioid and } \\
\text { NMDA recep- } \\
\text { tors; BH4 and } \\
\text { SAM synthesis }\end{array}$ \\
\hline
\end{tabular}

AhR: Aryl Hydrocarbon Receptor; BBB: Blood Brain Barrier; BH4: Tetrahydrobiopterin; FXR: Farnesoid X Receptor; GPR41: G-protein coupled receptor 41; GPR43: G-protein coupled receptor 43; GPR81: G-protein coupled receptor 81; GTP: Guanosine triphosphate; HDACi: Histone deacetylase inhibitor; MDD: Major Depressive Disorder; NT: Neurotransmitter; PXR: Pregnane X receptor; SAM: Sadenosylmethionine; SCFA: Short-Chain Fatty Acids; TGR5: Takeda G-protein receptor 5; TMA: Trimethylamine; TMAO: Trimethylamine $\mathrm{N}$-oxide; TUDCA: Tauroursodeoxycholic acids; VDR: Vitamin D Receptor

\section{ACKNOWLEDGMENTS}

Giorgia Caspani is supported by the MRC (grant number

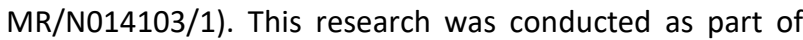
CAN-BIND, an Integrated Discovery Program supported by the Ontario Brain Institute, which is an independent nonprofit corporation, funded partially by the Ontario Government.

\section{CONFLICT OF INTEREST}

The authors declare no conflict of interest.

\section{REFERENCES}

1. Culligan EP, Marchesi JR, Hill C, and Sleator RD (2012). Mining the human gut microbiome for novel stress resistance genes. Gut Microbes 3(4): 394-397. doi: 10.4161/gmic.20984

2. Heijtz RD, Wang S, Anuar F, Qian Y, Bjorkholm B, Samuelsson A, Hibberd ML, Forssberg $H$, and Pettersson $S$ (2011). Normal gut microbiota modulates brain development and behavior. Proc Natl Acad Sci 108(7): 3047-3052. doi: 10.1073/pnas.1010529108

3. Aziz $Q$, and Thompson DG (1998). Brain-gut axis in health and disease. Gastroenterology 114(3): 559-578. doi: 10.1016/s00165085(98)70540-2

4. Borre YE, O'Keeffe GW, Clarke G, Stanton C, Dinan TG, and Cryan JF

\section{COPYRIGHT}

(C) 2019 Caspani et al. This is an open-access article released under the terms of the Creative Commons Attribution (CC BY) license, which allows the unrestricted use, distribution, and reproduction in any medium, provided the original author and source are acknowledged.

Please cite this article as: Giorgia Caspani, Sidney Kennedy, Jane Foster and Jonathan Swann (2019). Gut microbial metabolites in depression: understanding the biochemical mechanisms. Microbial Cell 6(10): 454-481. doi: 10.15698/mic2019.10.693

(2014). Microbiota and neurodevelopmental windows: implications for brain disorders. Trends Mol Med 20(9): 509-518. doi: 10.1016/j.molmed.2014.05.002

5. Sudo N, Chida Y, Aiba Y, Sonoda J, Oyama N, Yu XN, Kubo C, and Koga $Y$ (2004). Postnatal microbial colonization programs the hypothalamic-pituitary-adrenal system for stress response in mice. J Physiol 558(1): 263-275. doi: 10.1113/jphysiol.2004.063388

6. American Psychiatric Association (2013). Diagnostic and statistical manual of mental disorders: DSM-5. American Psychiatric Association.

7. Chung YCE, Chen HC, Chou HCL, Chen IM, Lee MS, Chuang LC, Liu 
YW, Lu ML, Chen $\mathrm{CH}$, Wu CH, Huang MC, Liao SC, Ni YH, Lai MS, Shih WL, and Kuo PH (2019). Exploration of microbiota targets for major depressive disorder and mood related traits. J Psychiatr Res 111: 7482. doi: 10.1016/j.jpsychires.2019.01.016

8. Jiang $H$, Ling $Z$, Zhang $Y$, Mao $H$, Ma Z, Yin $Y$, Wang $W$, Tang $W$, Tan $Z$, Shi J, Li L, and Ruan B (2015). Altered fecal microbiota composition in patients with major depressive disorder. Brain Behav Immun 48: 186194. doi: 10.1016/j.bbi.2015.03.016

9. Naseribafrouei A, Hestad K, Avershina E, Sekelja M, Linløkken A Wilson R, and Rudi $K$ (2014). Correlation between the human fecal microbiota and depression. Neurogastroenterol Motil 26(8): 11551162. doi: $10.1111 / \mathrm{nmo} .12378$

10. Zheng $P$, Zeng $B$, Zhou $C$, Liu M, Fang Z, Xu X, Zeng L, Chen J, Fan S, Du $X$, Zhang $X$, Yang D, Yang Y, Meng H, Li W, Melgiri ND, Licinio J, Wei $H$, and Xie $P(\mathbf{2 0 1 6})$. Gut microbiome remodeling induces depressivelike behaviors through a pathway mediated by the host's metabolism. Mol Psychiatry 21(6): 786-796. doi: 10.1038/mp.2016.44

11. Valles-Colomer M, Falony G, Darzi Y, Tigchelaar EF, Wang J, Tito RY Schiweck C, Kurilshikov A, Joossens M, Wijmenga C, Claes S, Van Oudenhove L, Zhernakova A, Vieira-Silva S, and Raes J (2019). The neuroactive potential of the human gut microbiota in quality of life and depression. Nat Microbiol 4(4):623-632. doi: 10.1038/s41564018-0337-x

12. Galley JD, Nelson MC, Yu Z, Dowd SE, Walter J, Kumar PS, Lyte M, and Bailey MT (2014). Exposure to a social stressor disrupts the community structure of the colonic mucosa-associated microbiota. BMC Microbiol 14:189. doi: 10.1186/1471-2180-14-189

13. Crumeyrolle-Arias M, Jaglin M, Bruneau A, Vancassel S, Cardona A, Daugé $V$, Naudon L, and Rabot $S$ (2014). Absence of the gut microbiota enhances anxiety-like behavior and neuroendocrine response to acute stress in rats. Psychoneuroendocrinology 42:207-17. doi: 10.1016/j.psyneuen.2014.01.014

14. Kelly JR, Borre Y, O’ Brien C, Patterson E, El Aidy S, Deane J, Kennedy PJ, Beers S, Scott K, Moloney G, Hoban AE, Scott L, Fitzgerald P, Ross P, Stanton C, Clarke G, Cryan JF, and Dinan TG (2016). Transferring the blues: Depression-associated gut microbiota induces neurobehavioural changes in the rat. J Psychiatr Res 82: 109-118. doi: 10.1016/j.jpsychires.2016.07.019

15. Huang $Y$, Shi $X$, Li Z, Shen $Y$, Shi $X$, Wang L, Li G, Yuan $Y$, Wang J, Zhang $Y$, Zhao L, Zhang $M$, Kang $Y$, and Liang $Y$ (2018). Possible association of firmicutes in the gut microbiota of patients with major depressive disorder. Neuropsychiatr Dis Treat 14:3329-3337. doi: 10.2147/NDT.S188340

16. O'Mahony SM, Clarke G, Borre YE, Dinan TG, and Cryan JF (2015). Serotonin, tryptophan metabolism and the brain-gut-microbiome axis. Behav Brain Res 277: 32-48. doi: 10.1016/j.bbr.2014.07.027

17. Heijtz Diaz $R$, Wang $S$, Anuard $F$, Qian $Y$, Björkholmd $B$, Samuelssond A, Hibberdc ML, Forssberg $H$, and Pettersson S (2011). Normal gut microbiota modulates brain development and behavior. Proc Natl Acad Sci 108(7): 3047-3052. doi: 10.1073/pnas.1010529108

18. Neufeld KM, Kang N, Bienenstock J, and Foster JA (2011). Reduced anxiety-like behavior and central neurochemical change in germ-free mice. Neurogastroenterol Motil 23(3): 255-64. doi: 10.1111/j.13652982.2010.01620.x

19. Hoban AE, Moloney RD, Golubeva A V., McVey Neufeld KA, O'Sullivan O, Patterson E, Stanton C, Dinan TG, Clarke G, and Cryan JF (2016). Behavioural and neurochemical consequences of chronic gut microbiota depletion during adulthood in the rat. Neuroscience 339: 463-477. doi: 10.1016/j.neuroscience.2016.10.003

20. Ressler KJ, and Mayberg HS (2007). Targeting abnormal neural circuits in mood and anxiety disorders: From the laboratory to the

\section{clinic. Nat Neurosci 10(9):1116-24. doi: 10.1038/nn1944}

21. Luheshi GN, Bluthé RM, Rushforth $D$, Mulcahy $N$, Konsman JP, Goldbach M, and Dantzer R (2000). Vagotomy attenuates the behavioural but not the pyrogenic effects of interleukin-1 in rats. Auton Neurosci 85(1-3):127-32. doi: 10.1016/S1566-0702(00)00231-9

22. Konsman JP, Luheshi GN, Bluthé RM, and Dantzer R (2000). The vagus nerve mediates behavioural depression, but not fever, in response to peripheral immune signals; a functional anatomical analysis. Eur J Neurosci 12(12):4434-46. doi: 10.1046/j.0953816X.2000.01319.x

23. Caspani G, Corbet Burcher G, Garralda ME, Cooper M, Pierce CM, Als LC, and Nadel S (2018). Inflammation and psychopathology in children following PICU admission: An exploratory study. Evid Based Ment Health 21(4):139-144. doi: 10.1136/ebmental-2018-300027

24. Fung TC, Olson CA, and Hsiao EY (2017). Interactions between the microbiota, immune and nervous systems in health and disease. Nat Neurosci 20(2): 145-155. doi: 10.1038/nn.4476

25. Galland L (2014). The Gut Microbiome and the Brain. J Med Food 17(12): 1261-1272. doi: 10.1089/jmf.2014.7000

26. Heumann D, Barras C, Severin A, Glauser MP, and Tomasz A (1994). Gram-positive cell walls stimulate synthesis of tumor necrosis factor alpha and interleukin-6 by human monocytes. Infect Immun 62(7): 2715-2721. PMID: 7516310

27. Arentsen T, Qian Y, Gkotzis S, Femenia T, Wang T, Udekwu K, Forssberg $\mathrm{H}$, and Diaz Heijtz R (2017). The bacterial peptidoglycansensing molecule Pglyrp2 modulates brain development and behavior. Mol Psychiatry 22(2): 257-266. doi: 10.1038/mp.2016.182

28. Ulevitch RJ, and Tobias PS (2003). Receptor-Dependent Mechanisms of Cell Stimulation by Bacterial Endotoxin. Annu Rev Immunol 13(1): 437-457. doi: 10.1146/annurev.iy.13.040195.002253

29. Grigoleit JS, Kullmann JS, Wolf OT, Hammes F, Wegner A, Jablonowski S, Engler H, Gizewski E, Oberbeck R, and Schedlowski M (2011). Dose-dependent effects of endotoxin on neurobehavioral functions in humans. PLoS One 6(12): e28330. doi: 10.1371/journal.pone.0028330

30. Hoyles L, Snelling T, Umlai UK, Nicholson JK, Carding SR, Glen RC, and McArthur $S$ (2018). Microbiome-host systems interactions: Protective effects of propionate upon the blood-brain barrier. Microbiome 6(1):55. doi: 10.1186/s40168-018-0439-y

31. Sternberg EM (2006). Neural regulation of innate immunity: A coordinated nonspecific host response to pathogens. Nat Rev Immunol 6(4):318-28. doi: 10.1038/nri1810

32. Wikoff WR, Anfora AT, Liu J, Schultz PG, Lesley SA, Peters EC, and Siuzdak $G$ (2009). Metabolomics analysis reveals large effects of gut microflora on mammalian blood metabolites. Proc Natl Acad Sci 106(10): 3698-3703. doi: 10.1073/pnas.0812874106

33. Nicholson JK, Holmes E, Kinross J, Burcelin R, Gibson G, Jia W, and Pettersson S (2012). Host-Gut Microbiota Metabolic Interactions. Science 336(6086):1262-7. doi: 10.1126/science.1223813

34. Frost G, Sleeth ML, Sahuri-Arisoylu M, Lizarbe B, Cerdan S, Brody L, Anastasovska J, Ghourab S, Hankir M, Zhang S, Carling D, Swann JR, Gibson G, Viardot A, Morrison D, Thomas EL, and Bell JD (2014). The short-chain fatty acid acetate reduces appetite via a central homeostatic mechanism. Nat Commun 5: 3611 . doi: 10.1038/ncomms4611

35. Berger M, Gray JA, and Roth BL (2009). The Expanded Biology of Serotonin. Annu Rev Med 60(1): 355-366. doi: 10.1146/annurev.med.60.042307.110802

36. Hyland NP, and Cryan JF (2010). A gut feeling about GABA: Focus on GABAB receptors. Front Pharmacol 1:124. doi: 


\subsection{9/fphar.2010.00124}

37. Barrett E, Ross RP, O'Toole PW, Fitzgerald GF, and Stanton C (2012). $y$-Aminobutyric acid production by culturable bacteria from the human intestine. J Appl Microbiol 113(2): 411-417. doi: 10.1111/j.1365-2672.2012.05344.x

38. Pokusaeva K, Johnson C, Luk B, Uribe G, Fu Y, Oezguen N, Matsunami RK, Lugo M, Major A, Mori-Akiyama Y, Hollister EB, Dann SM, Shi XZ, Engler DA, Savidge T, and Versalovic J (2017). GABAproducing Bifidobacterium dentium modulates visceral sensitivity in the intestine. Neurogastroenterol Motil 29(1). doi: 10.1111/nmo.12904

39. Cho YR, Chang JY, and Chang HC (2007). Production of Yaminobutyric acid (GABA) by Lactobacillus buchneri isolated from Kimchi and its neuroprotective effect on neuronal cells. J Microbiol Biotechnol 17(1):104-9. PMID: 18051360

40. Komatsuzaki N, Shima J, Kawamoto S, Momose H, and Kimura $T$ (2005). Production of $\gamma$-aminobutyric acid (GABA) by Lactobacillus paracasei isolated from traditional fermented foods. Food Microbiol 22(6): 497-504. doi: 10.1016/j.fm.2005.01.002

41. Siragusa S, De Angelis M, Di Cagno R, Rizzello CG, Coda R, and Gobbetti $M$ (2007). Synthesis of $\gamma$-aminobutyric acid by lactic acid bacteria isolated from a variety of Italian cheeses. Appl Environ Microbiol 73(22):7283-90. doi: 10.1128/AEM.01064-07

42. Shishov VA, Kirovskaya TA, Kudrin VS, and Oleskin A V. (2009). Amine neuromediators, their precursors, and oxidation products in the culture of Escherichia coli K-12. Appl Biochem Microbiol 45(5): 494-497. doi: 10.1134/s0003683809050068

43. Tsavkelova E, Botvinko I, Kudrin V, and Oleskin A (2000). Detection of neurotransmitter amines in microorganisms with the use of highperformance liquid chromatography. Dokl Biochem 372(1-6): 115-7. PMID: 10935181

44. Stanaszek PM, Snell JF, and O'Neill JJ (1977). Isolation, extraction, and measurement of acetylcholine from Lactobacillus plantarum. Appl Environ Microbiol 34(2):237-9. PMID: 907345

45. Asano $Y$, Hiramoto $T$, Nishino R, Aiba $Y$, Kimura T, Yoshihara K, Koga $Y$, and Sudo $N$ (2012). Critical role of gut microbiota in the production of biologically active, free catecholamines in the gut lumen of mice. Am J Physiol - Gastrointest Liver Physiol 303: G1288-95. doi: 10.1152/ajpgi.00341.2012

46. Matsumoto $M$, Kibe $R$, Ooga $T$, Aiba $Y$, Sawaki $E$, Koga $Y$, and Benno $Y$ (2013). Cerebral low-molecular metabolites influenced by intestinal microbiota: a pilot study. Front Syst Neurosci 7: 9. doi: 10.3389/fnsys.2013.00009

47. Sampson TR, and Mazmanian SK (2015). Control of brain development, function, and behavior by the microbiome. Cell Host Microbe 17:565-576. doi: 10.1016/j.chom.2015.04.011

48. Yano JM, Yu K, Donaldson GP, Shastri GG, Ann P, Ma L, Nagler CR, Ismagilov RF, Mazmanian SK, and Hsiao EY (2015). Indigenous bacteria from the gut microbiota regulate host serotonin biosynthesis. Cell 161(2): 264-276. doi: 10.1016/j.cell.2015.02.047

49. Clarke G, Grenham S, Scully P, Fitzgerald P, Moloney RD, Shanahan $F$, Dinan TG, and Cryan JF (2013). The microbiome-gut-brain axis during early life regulates the hippocampal serotonergic system in a sex-dependent manner. Mol Psychiatry 18(6): 666-673. doi: 10.1038/mp.2012.77

50. Janik R, Thomason LAM, Stanisz AM, Forsythe P, Bienenstock J, and Stanisz GJ (2016). Magnetic resonance spectroscopy reveals oral Lactobacillus promotion of increases in brain GABA, N-acetyl aspartate and glutamate. Neuroimage 125: 988-995. doi: 10.1016/j.neuroimage.2015.11.018
51. Ko CY, Lin HTV, and Tsai GJ (2013). Gamma-aminobutyric acid production in black soybean milk by Lactobacillus brevis FPA 3709 and the antidepressant effect of the fermented product on a forced swimming rat model. Process Biochem 48(4): 559-568. doi: 10.1016/j.procbio.2013.02.021

52. Velagapudi VR, Hezaveh R, Reigstad CS, Gopalacharyulu P, Yetukuri L, Islam S, Felin J, Perkins R, Borén J, Orešič M, and Bäckhed F (2010). The gut microbiota modulates host energy and lipid metabolism in mice. J Lipid Res 51(5): 1101-1112. doi: 10.1194/jlr.M002774

53. Matsumoto $M$, Kibe $R$, Ooga $T$, Aiba $Y$, Kurihara $S$, Sawaki E, Koga $Y$, and Benno $Y$ (2012). Impact of intestinal microbiota on intestinal luminal metabolome. Sci Rep 2: 233. doi: 10.1038/srep00233

54. Sharon G, Garg N, Debelius J, Knight R, Dorrestein PC, and Mazmanian SK (2014). Specialized metabolites from the microbiome in health and disease. Cell Metab 20:719-730. doi: 10.1016/j.cmet.2014.10.016

55. Bravo JA, Forsythe P, Chew M V., Escaravage E, Savignac HM, Dinan TG, Bienenstock J, and Cryan JF (2011). Ingestion of Lactobacillus strain regulates emotional behavior and central GABA receptor expression in a mouse via the vagus nerve. Proc Natl Acad Sci 108(38): 16050-16055. doi: 10.1073/pnas.1102999108

56. Baganz NL, and Blakely RD (2013). A dialogue between the immune system and brain, spoken in the language of serotonin. ACS Chem Neurosci 4(1):48-63. doi: 10.1021/cn300186b

57. Auteri M, Zizzo MG, and Serio R (2015). GABA and GABA receptors in the gastrointestinal tract: from motility to inflammation. Pharmacol Res 93: 11-21. doi: 10.1016/j.phrs.2014.12.001

58. Desbonnet L, Garrett L, Clarke G, Bienenstock J, and Dinan TG (2008). The probiotic Bifidobacteria infantis: An assessment of potential antidepressant properties in the rat. J Psychiatr Res 43(2): 164-174. doi: 10.1016/j.jpsychires.2008.03.009

59. Breit S, Kupferberg A, Rogler G, and Hasler G (2018). Vagus nerve as modulator of the brain-gut axis in psychiatric and inflammatory disorders. Front Psychiatry 9:44. doi: 10.3389/fpsyt.2018.00044

60. Strandwitz $P$ (2018). Neurotransmitter modulation by the gut microbiota. Brain Res 1693:128-133. doi 10.1016/j.brainres.2018.03.015

61. Lyte M (2011). Probiotics function mechanistically as delivery vehicles for neuroactive compounds: Microbial endocrinology in the design and use of probiotics. BioEssays 33(8): 574-581. doi: $10.1002 /$ bies. 201100024

62. Bergman EN (2017). Energy contributions of volatile fatty acids from the gastrointestinal tract in various species. Physiol Rev 70(2): 567-590. doi: 10.1152/physrev.1990.70.2.567

63. van de Wouw M, Boehme M, Lyte JM, Wiley N, Strain C, O'Sullivan O, Clarke G, Stanton C, Dinan TG, and Cryan JF (2018). Short-chain fatty acids: microbial metabolites that alleviate stress-induced braingut axis alterations. J Physiol 596(20): 4923-4944. doi: 10.1113/JP276431

64. Chen JJ, Zhou CJ, Liu Z, Fu YY, Zheng P, Yang DY, Li Q, Mu J, Wei YD, Zhou JJ, Huang $\mathrm{H}$, and Xie $\mathrm{P}$ (2015). Divergent Urinary Metabolic Phenotypes between Major Depressive Disorder and Bipolar Disorder Identified by a Combined GC-MS and NMR Spectroscopic Metabonomic Approach. J Proteome Res 14(8): 3382-3389. doi: 10.1021/acs.jproteome.5b00434

65. Skonieczna-żydecka K, Grochans E, Maciejewska D, Szkup M, Schneider-Matyka D, Jurczak A, Łoniewski I, Kaczmarczyk M, Marlicz W, Czerwińska-Rogowska M, Pełka-Wysiecka J, Dec K, and Stachowska E (2018). Faecal short chain fatty acids profile is changed in Polish depressive women. Nutrients 10(12): E1939. doi: 


\subsection{0/nu10121939}

66. Stilling RM, van de Wouw M, Clarke G, Stanton C, Dinan TG, and Cryan JF (2016). The neuropharmacology of butyrate: The bread and butter of the microbiota-gut-brain axis? Neurochem Int 99:110-132. doi: 10.1016/j.neuint.2016.06.011

67. Cani PD, and Knauf C (2016). How gut microbes talk to organs: The role of endocrine and nervous routes. Mol Metab 5(9):743-752. doi: 10.1016/j.molmet.2016.05.011

68. Bourassa MW, Alim I, Bultman SJ, and Ratan RR (2016). Butyrate, neuroepigenetics and the gut microbiome: Can a high fiber diet improve brain health? Neurosci Lett 625:56-63. doi: 10.1016/j.neulet.2016.02.009

69. Nøhr MK, Pedersen MH, Gille A, Egerod KL, Engelstoft MS, Husted AS, Sichlau RM, Grunddal K V., Poulsen SS, Han S, Jones RM, Offermanns S, and Schwartz TW (2013). GPR41/FFAR3 and GPR43/FFAR2 as cosensors for short-chain fatty acids in enteroendocrine cells vs FFAR3 in enteric neurons and FFAR2 in enteric leukocytes. Endocrinology 154(10): 3552-3564. doi: 10.1210/en.2013-1142

70. Samuel BS, Shaito A, Motoike T, Rey FE, Backhed F, Manchester JK, Hammer RE, Williams SC, Crowley J, Yanagisawa M, and Gordon J (2008). Effects of the gut microbiota on host adiposity are modulated by the short-chain fatty-acid binding $G$ protein-coupled receptor, Gpr41. Proc Natl Acad Sci 105(43): 16767-16772. doi: 10.1073/pnas.0808567105

71. Tolhurst G, Heffron H, Lam YS, Parker HE, Habib AM, Diakogiannaki E, Cameron J, Grosse J, Reimann F, and Gribble FM (2012). Short-chain fatty acids stimulate glucagon-like peptide-1 secretion via the Gprotein-coupled receptor FFAR2. Diabetes 61(2): 364-371. doi: 10.2337/db11-1019

72. Everard A, Lazarevic V, Gaïa N, Johansson M, Ståhlman M, Backhed F, Delzenne NM, Schrenzel J, François P, and Cani PD (2014). Microbiome of prebiotic-treated mice reveals novel targets involved in host response during obesity. ISME J 8(10): 2116-2130. doi: 10.1038/ismej.2014.45

73. Priori $D$, Colombo $M$, Clavenzani $P$, Jansman AJM, Lallès JP, Trevisi $P$, and Bosi $P$ (2015). The olfactory receptor OR51E1 is present along the gastrointestinal tract of pigs, co-localizes with enteroendocrine cells and is modulated by intestinal microbiota. PLoS One 10(6): e0129501. doi: 10.1371/journal.pone.0129501

74. López Soto EJ, Gambino LO, and Mustafá ER (2014). Free fatty acid receptor 3 is a key target of short chain fatty acid. Channels 8(3): 169171. doi: 10.4161/chan. 28956

75. Nøhr MK, Egerod KL, Christiansen SH, Gille A, Offermanns S, Schwartz TW, and Møller M (2015). Expression of the short chain fatty acid receptor GPR41/FFAR3 in autonomic and somatic sensory ganglia. Neuroscience 290: 126-137. doi: 10.1016/j.neuroscience.2015.01.040

76. Goswami C, Iwasaki Y, and Yada T (2018). Short-chain fatty acids suppress food intake by activating vagal afferent neurons. J Nutr Biochem 57: 130-135. doi: 10.1016/j.jnutbio.2018.03.009

77. Karuri AR, Dobrowsky E, and Tannock IF (1993). Selective cellular acidification and toxicity of weak organic acids in an acidic microenvironment. $\mathrm{Br}$ J Cancer 68(6): 1080-1087. doi: 10.1038/bjc.1993.485

78. Vijay N, and Morris M (2014). Role of Monocarboxylate Transporters in Drug Delivery to the Brain. Curr Pharm Des 20(10): 1487-1498. doi: 10.2174/13816128113199990462

79. Byrne CS, Chambers ES, Alhabeeb H, Chhina N, Morrison DJ, Preston T, Tedford C, Fitzpatrick J, Irani C, Busza A, Garcia-Perez I, Fountana S, Holmes E, Goldstone AP, and Frost GS (2016). Increased colonic propionate reduces anticipatory reward responses in the human striatum to high-energy foods. Am J Clin Nutr 104(1): 5-14. doi: 10.3945/ajcn.115.126706

80. Pizzagalli DA, Holmes AJ, Dillon DG, Goetz EL, Birk JL, Bogdan R, Dougherty DD, losifescu D V., Rauch SL, and Fava M (2009). Reduced caudate and nucleus accumbens response to rewards in unmedicated individuals with major depressive disorder. Am J Psychiatry 166(6): 702-710. doi: 10.1176/appi.ajp.2008.08081201

81. Corrêa-Oliveira R, Fachi JL, Vieira A, Sato FT, and Vinolo MAR (2016). Regulation of immune cell function by short-chain fatty acids. Clin TransI Immunol 5(4):e73. doi: 10.1038/cti.2016.17

82. Erny D, De Angelis ALH, Jaitin D, Wieghofer P, Staszewski O, David E, Keren-Shaul H, Mahlakoiv T, Jakobshagen K, Buch T, Schwierzeck V, Utermöhlen O, Chun E, Garrett WS, Mccoy KD, Diefenbach A, Staeheli $P$, Stecher B, Amit I, and Prinz M (2015). Host microbiota constantly control maturation and function of microglia in the CNS. Nat Neurosci 18(7): 965-977. doi: 10.1038/nn.4030

83. Huuskonen J, Suuronen T, Nuutinen T, Kyrylenko S, and Salminen A (2004). Regulation of microglial inflammatory response by sodium butyrate and short-chain fatty acids. Br J Pharmacol 141(5): 874-880. doi: 10.1038/sj.bjp.0705682

84. Tedelind S, Westberg F, Kjerrulf M, and Vidal A (2007). Antiinflammatory properties of the short-chain fatty acids acetate and propionate: A study with relevance to inflammatory bowel disease. World J Gastroenterol 13(20): 2826-2832. doi: 10.3748/wjg.v13.i20.2826

85. MacFabe DF, Cain DP, Rodriguez-Capote K, Franklin AE, Hoffman JE, Boon F, Taylor AR, Kavaliers M, and Ossenkopp KP (2007). Neurobiological effects of intraventricular propionic acid in rats: Possible role of short chain fatty acids on the pathogenesis and characteristics of autism spectrum disorders. Behav Brain Res 176(1) 149-169. doi: 10.1016/j.bbr.2006.07.025

86. Trompette A, Gollwitzer ES, Yadava K, Sichelstiel AK, Sprenger N, Ngom-Bru C, Blanchard C, Junt T, Nicod LP, Harris NL, and Marsland BJ (2014). Gut microbiota metabolism of dietary fiber influences allergic airway disease and hematopoiesis. Nat Med 20(2): 159-166. doi: $10.1038 / \mathrm{nm} .3444$

87. Kim HJ, Leeds $P$, and Chuang DM (2009). The HDAC inhibitor, sodium butyrate, stimulates neurogenesis in the ischemic brain. J Neurochem 110(4): 1226-1240. doi: 10.1111/j.1471 4159.2009.06212.x

88. Yoo DY, Kim W, Nam SM, Kim DW, Chung JY, Choi SY, Yeo Sung Yoon, Won MH, and Hwang IK (2011). Synergistic effects of sodium butyrate, a histone deacetylase inhibitor, on increase of neurogenesis induced by pyridoxine and increase of neural proliferation in the mouse dentate gyrus. Neurochem Res 36(10): 1850-1857. doi: 10.1007/s11064-011-0503-5

89. MacFabe DF, Thomas RH, Foley KA, Mepham JR, Tichenoff $L$, and Possmayer $F$ (2010). Altered brain phospholipid and acylcarnitine profiles in propionic acid infused rodents: Further development of a potential model of autism spectrum disorders. J Neurochem 113(2): 515-529. doi: 10.1111/j.1471-4159.2010.06614.x

90. Frye RE, Sequeira JM, Quadros E V., James SJ, and Rossignol DA (2013). Cerebral folate receptor autoantibodies in autism spectrum disorder. Mol Psychiatry 18(3): 369-381. doi: 10.1038/mp.2011.175

91. Wei Y Bin, Melas PA, Wegener G, Mathe AA, and Lavebratt C (2015). Antidepressant-like effect of sodium butyrate is associated with an increase in tet1 and in 5-hydroxymethylation levels in the BDNF gene. Int J Neuropsychopharmacol 18(2): 1-10. doi: 10.1093/ijnp/pyu032

92. Misztak P, Pańczyszyn-Trzewik P, and Sowa-Kućma M (2018). Histone deacetylases (HDACs) as therapeutic target for depressive 
disorders. Pharmacol Reports 70(2): 398-408. doi: 10.1016/j.pharep.2017.08.001

93. Davie JR (2018). Inhibition of Histone Deacetylase Activity by Butyrate. J Nutr 133(7): 2485S-2493S. doi: 10.1093/jn/133.7.2485s

94. Schroeder FA, Lin CL, Crusio WE, and Akbarian S (2007). Antidepressant-Like Effects of the Histone Deacetylase Inhibitor, Sodium Butyrate, in the Mouse. Biol Psychiatry 62(1): 55-64. doi: 10.1016/j.biopsych.2006.06.036

95. Gundersen BB, and Blendy JA (2009). Effects of the histone deacetylase inhibitor sodium butyrate in models of depression and anxiety. Neuropharmacology 57(1): 67-74. doi: 10.1016/j.neuropharm.2009.04.008

96. Han A, Sung Y Bin, Chung SY, and Kwon MS (2014). Possible additional antidepressant-like mechanism of sodium butyrate: Targeting the hippocampus. Neuropharmacology 81: 292-302. doi: 10.1016/j.neuropharm.2014.02.017

97. Yamawaki $Y$, Fuchikami M, Morinobu S, Segawa M, Matsumoto T, and Yamawaki S (2012). Antidepressant-like effect of sodium butyrate (HDAC inhibitor) and its molecular mechanism of action in the rat hippocampus. World J Biol Psychiatry 13(6): 458-467. doi: 10.3109/15622975.2011.585663

98. Sarkar A, Chachra P, Kennedy P, Pena CJ, Desouza LA, Nestler EJ, and Vaidya VA (2014). Hippocampal HDAC4 contributes to postnatal fluoxetine-evoked depression-like behavior.

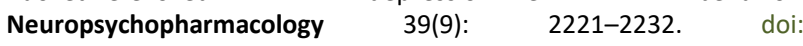
10.1038/npp.2014.73

99. Yamawaki Y, Yoshioka N, Nozaki K, Ito H, Oda K, Harada K, Shirawachi S, Asano S, Aizawa H, Yamawaki S, Kanematsu T, and Akagi H (2018). Sodium butyrate abolishes lipopolysaccharide-induced depression-like behaviors and hippocampal microglial activation in mice. Brain Res 1680: 13-38. doi: 10.1016/j.brainres.2017.12.004

100. Sun J, Wang F, Hong G, Pang M, Xu H, Li H, Tian F, Fang R, Yao Y, and Liu J (2016). Antidepressant-like effects of sodium butyrate and its possible mechanisms of action in mice exposed to chronic unpredictable mild stress. Neurosci Lett 618: 159-166. doi: 10.1016/j.neulet.2016.03.003

101. Nankova BB, Agarwal R, MacFabe DF, and La Gamma EF (2014). Enteric bacterial metabolites propionic and butyric acid modulate gene expression, including CREB-dependent catecholaminergic neurotransmission, in PC12 cells - Possible relevance to autism spectrum disorders. PLoS One 9(8): e103740. doi: 10.1371/journal.pone.0103740

102. Wang $P$, Zhang $Y$, Gong $Y$, Yang R, Chen $Z$, Hu W, Wu Y, Gao M, Xu $X$, Qin $Y$, and Huang $C$ (2018). Sodium butyrate triggers a functional elongation of microglial process via Akt-small RhoGTPase activation and HDACs inhibition. Neurobiol Dis 111: 12-25. doi: 10.1016/j.nbd.2017.12.006

103. Valvassori S, Resende W, Budni J, Dal-Pont G, Bavaresco D, Reus G, Carvalho A, Goncalves C, Furlanetto C, Streck E, and Quevedo J (2015). Sodium Butyrate, a Histone Deacetylase Inhibitor, Reverses Behavioral and Mitochondrial Alterations in Animal Models of Depression Induced by Early- or Late-life Stress. Curr Neurovasc Res 12(4): 312-320. doi: 10.2174/1567202612666150728121121

104. Aoyama M, Kotani J, and Usami M (2010). Butyrate and propionate induced activated or non-activated neutrophil apoptosis via HDAC inhibitor activity but without activating GPR-41/GPR-43 pathways. Nutrition 26(6): 653-661. doi: 10.1016/j.nut.2009.07.006

105. Li J, Hou L, Wang C, Jia X, Qin X, and Wu C (2018). Short Term Intrarectal Administration of Sodium Propionate Induces Antidepressant-Like Effects in Rats Exposed to Chronic Unpredictable Mild Stress. Front Psychiatry 9: 454. doi: 10.3389/fpsyt.2018.00454
106. Teraishi T, Hori H, Sasayama D, Matsuo J, Ogawa S, Ota M, Hattori K, Kajiwara M, Higuchi $T$, and Kunugi $H$ (2015). 13 Ctryptophan breath test detects increased catabolic turnover of tryptophan along the kynurenine pathway in patients with major depressive disorder. Sci Rep 5: 15994. doi: 10.1038/srep15994

107. El-Ansary $A K, B a c h a A B$, and Kotb $M$ (2012). Etiology of autistic features: the persisting neurotoxic effects of propionic acid. J Neuroinflammation 9: 74. doi: 10.1186/1742-2094-9-74

108. Kanski R, Sneeboer MAM, van Bodegraven EJ, Sluijs JA, Kropff W, Vermunt MW, Creyghton MP, De Filippis L, Vescovi A, Aronica E, van Tijn $P$, van Strien ME, and Hol EM (2014). Histone acetylation in astrocytes suppresses GFAP and stimulates a reorganization of the intermediate filament network. J Cell Sci 127(20): 4368-4380. doi: $10.1242 /$ jcs. 145912

109. Segain JP, Galmiche JP, Raingeard De La Blétière $D$, Bourreille $A$ Leray V, Gervois N, Rosales C, Ferrier L, Bonnet C, and Blottière HM (2000). Butyrate inhibits inflammatory responses through NFKB inhibition: Implications for Crohn's disease. Gut 47(3): 397-403. doi: 10.1136/gut.47.3.397

110. Patnala R, Arumugam T V., Gupta N, and Dheen ST (2017). HDAC Inhibitor Sodium Butyrate-Mediated Epigenetic Regulation Enhances Neuroprotective Function of Microglia During Ischemic Stroke. Mol Neurobiol 54(8): 6391-6411. doi: 10.1007/s12035-016-0149-z

111. Wang J, Wei Z, Zhang X, Wang $Y$, Yang $Z$, and Fu $Y$ (2017). Propionate protects against lipopolysaccharide-induced mastitis in mice by restoring blood-milk barrier disruption and suppressing inflammatory response. Front Immunol 8: 1108 . doi: 10.3389/fimmu.2017.01108

112. De Almeida LMV, Funchal C, Gottfried C, Wajner M, and PessoaPureur R (2006). Propionic acid induces cytoskeletal alterations in cultured astrocytes from rat cerebral cortex. Metab Brain Dis 21(1): 51-62. doi: 10.1007/s11011-006-9002-9

113. MacFabe DF (2012). Short-chain fatty acid fermentation products of the gut microbiome: implications in autism spectrum disorders. Microb Ecol Heal Dis 23. doi: 10.3402/mehd.v23i0.19260

114. Shultz SR, MacFabe DF, Martin S, Jackson J, Taylor R, Boon F, Ossenkopp KP, and Cain DP (2009). Intracerebroventricular injections of the enteric bacterial metabolic product propionic acid impair cognition and sensorimotor ability in the Long-Evans rat: Further development of a rodent model of autism. Behav Brain Res 200(1): 33-41. doi: 10.1016/j.bbr.2008.12.023

115. Burokas A, Arboleya S, Moloney RD, Peterson VL, Murphy K, Clarke G, Stanton C, Dinan TG, and Cryan JF (2017). Targeting the Microbiota-Gut-Brain Axis: Prebiotics Have Anxiolytic and Antidepressant-like Effects and Reverse the Impact of Chronic Stress in Mice. Biol Psychiatry 82(7): 472-487. doi: 10.1016/j.biopsych.2016.12.031

116. Gao X, Zheng X, Li Z, Zhou Y, Sun H, Zhang L, Guo X, Du G, and Qin $X$ (2011). Metabonomic study on chronic unpredictable mild stress and intervention effects of Xiaoyaosan in rats using gas chromatography coupled with mass spectrometry. J Ethnopharmacol 137(1):690-9. doi: 10.1016/j.jep.2011.06.024

117. Liu CC, Wu YF, Feng GM, Gao XX, Zhou YZ, Hou WJ, Qin XM, Du $\mathrm{GH}$, and Tian JS (2015). Plasma-metabolite-biomarkers for the therapeutic response in depressed patients by the traditional Chinese medicine formula Xiaoyaosan: A1H NMR-based metabolomics approach. J Affect Disord 185: 156-163. doi: 10.1016/j.jad.2015.05.005

118. Primec $M$, Mičetić-Turk $D$, and Langerholc $T$ (2017). Analysis of short-chain fatty acids in human feces: A scoping review. Anal Biochem 526:9-21. doi: 10.1016/j.ab.2017.03.007 
119. Miranda PM, De Palma G, Serkis V, Lu J, Louis-Auguste MP, McCarville JL, Verdu EF, Collins SM, and Bercik P (2018). High salt diet exacerbates colitis in mice by decreasing Lactobacillus levels and butyrate production. Microbiome 6(1):57. doi: 10.1186/s40168-018 0433-4

120. Rooks MG, and Garrett WS (2016). Gut microbiota, metabolites and host immunity. Nat Rev Immunol 16(6):341-52. doi: 10.1038/nri.2016.42

121. Chambers ES, Morrison DJ, and Frost G (2015). Control of appetite and energy intake by SCFA: What are the potential underlying mechanisms? Proc Nutr Soc 74(3):328-36. doi: 10.1017/S0029665114001657

122. Comalada M, Bailón E, De Haro O, Lara-Villoslada F, Xaus J, Zarzuelo A, and Gálvez J (2006). The effects of short-chain fatty acids on colon epithelial proliferation and survival depend on the cellular phenotype. J Cancer Res Clin Oncol 132(8):487-97. doi: 10.1007/s00432-006-0092-x

123. Pluznick JL (2013). A novel SCFA receptor, the microbiota, and blood pressure regulation. Gut Microbes 5(2):202-7. doi: 10.4161/gmic. 27492

124. den Besten G, van Eunen K, Groen AK, Venema K, Reijngoud D-J, and Bakker BM (2013). The role of short-chain fatty acids in the interplay between diet, gut microbiota, and host energy metabolism. $J$ Lipid Res 54(9):2325-40. doi: 10.1194/jlr.r036012

125. Morrison DJ, and Preston T (2016). Formation of short chain fatty acids by the gut microbiota and their impact on human metabolism. Gut Microbes 7(3):189-200. doi: 10.1080/19490976.2015.1134082

126. Pan X, Chen F, Wu T, Tang H, and Zhao Z (2009). Prebiotic oligosaccharides change the concentrations of short-chain fatty acids and the microbial population of mouse bowel. J Zhejiang Univ Sci B 10(4):258-63. doi: 10.1631/jzus.b0820261

127. Nagpal R, Wang S, Ahmadi S, Hayes J, Gagliano J, Subashchandrabose S, Kitzman DW, Becton T, Read R, and Yadav H (2018). Human-origin probiotic cocktail increases short-chain fatty acid production via modulation of mice and human gut microbiome. Sci Rep 8(1):12649. doi: 10.1038/s41598-018-30114-4

128. Richard DM, Dawes MA, Mathias CW, Acheson A, Hill-Kapturczak $\mathrm{N}$, and Dougherty DM (2009). L-tryptophan: Basic metabolic functions, behavioral research and therapeutic indications. Int J Tryptophan Res 2:45-60. doi: 10.4137/ijtr.s2129

129. Young SN (2013). Acute tryptophan depletion in humans: A review of theoretical, practical and ethical aspects. J Psychiatry Neurosci 38(5):294-305. doi: 10.1503/jpn.120209

130. Nishizawa S, Benkelfat C, Young SN, Leyton M, Mzengeza S, de Montigny C, Blier P, and Diksic M (1997). Differences between males and females in rates of serotonin synthesis in human brain. Proc Nat Acad Sci 94(10):5308-13. doi: 10.1073/pnas.94.10.5308

131. Feder A, Skipper J, Blair JR, Buchholz K, Mathew SJ, Schwarz M, Doucette JT, Alonso A, Collins KA, Neumeister A, and Charney DS (2011). Tryptophan depletion and emotional processing in healthy volunteers at high risk for depression. Biol Psychiatry 69(8):804-7. doi: 10.1016/j.biopsych.2010.12.033

132. Van Der Veen FM, Evers EAT, Deutz NEP, and Schmitt JAJ (2007). Effects of acute tryptophan depletion on mood and facial emotion perception related brain activation and performance in healthy women with and without a family history of depression. Neuropsychopharmacology 32(1):216-24. doi: 10.1038/sj.npp.1301212

133. Smith KA, Fairburn CG, and Cowen PJ (1997). Relapse of depression after vapid depletion of tryptophan. Lancet 349(9056):915-9. doi: 10.1016/S0140-6736(96)07044-4
134. Moreno FA, Gelenberg AJ, Heninger GR, Potter RL, McKnight KM, Allen J, Phillips AP, and Delgado PL (1999). Tryptophan depletion and depressive vulnerability. Biol Psychiatry 46(4):498-505. doi: 10.1016/S0006-3223(99)00095-5

135. Booij L, Van Der Does AJW, Haffmans PMJ, Riedel WJ, Fekkes D, and Blum MJB (2005). The effects of high-dose and low-dose tryptophan depletion on mood and cognitive functions of remitted depressed patients. J Psychopharmacol 19(3):267-75. doi: $10.1177 / 0269881105051538$

136. Booij L, Van Der Does AJW, Haffmans PMJ, and Riedel WJ (2005). Acute tryptophan depletion in depressed patients treated with a selective serotonin-noradrenalin reuptake inhibitor: Augmentation of antidepressant response? J Affect Disord 86(2-3):305-11. doi: 10.1016/j.jad.2005.01.012

137. Delgado PL, Price LH, Miller HL, Salomon RM, Licinio J, Krystal JH, Heninger GR, and Charney DS (1991). Rapid serotonin depletion as a provocative challenge test for patients with major depression: relevance to antidepressant action and the neurobiology of depression. Psychopharmacol Bull 27(3):321-30. PMID: 1775606.

138. Müller N, and Schwarz MJ (2008). A psychoneuroimmunological perspective to Emil Kraepelins dichotomy: Schizophrenia and major depression as inflammatory CNS disorders. Eur Arch Psychiatry Clin Neurosci 258 (Suppl 2):97-106. doi: 10.1007/s00406-008-2012-3

139. Melillo G, Cox GW, Biragyn A, Sheffler LA, and Varesio L (1994). Regulation of nitric-oxide synthase mRNA expression by interferon- $\nu$ and picolinic acid. J Biol Chem 269(11):8128-33. PMID: 7510678

140. Oxenkrug G (2005). Antioxidant effects of $\mathrm{N}$-acetylserotonin: Possible mechanisms and clinical implications. Ann N Y Acad Sci 1053:334-47. doi: 10.1196/annals.1344.029

141. Lapin IP, and Oxenkrug GF (1969). Intensification of the central serotoninergic processes as a possible determinant of the thymoleptic effect. Lancet 1(7586):132-6. doi: 10.1016/s0140-6736(69)91140-4

142. Pardridge WM. (1979). The role of blood-brain barrier transport of tryptophan and other neutral amino acids in the regulation of substrate-limited pathways of brain amino acid metabolism. J Neural Transm Suppl 15: 43-54. doi: 10.1007/978-3-7091-2243-3_4

143. Li G, and Young KD (2013). Indole production by the tryptophanase TnaA in escherichia coli is determined by the amount of exogenous tryptophan. Microbiol 159(Pt 2):402-10. doi: 10.1099/mic.0.064139-0

144. Lee $\mathrm{JH}$, and Lee J (2010). Indole as an intercellular signal in microbial communities. FEMS Microbiol Rev 34(4):426-44. doi: 10.1111/j.1574-6976.2009.00204.x

145. Chimerel C, Emery E, Summers DK, Keyser U, Gribble FM, and Reimann F (2014). Bacterial Metabolite Indole Modulates Incretin Secretion from Intestinal Enteroendocrine L Cells. Cell Rep 9(4):1202-8. doi: 10.1016/j.celrep.2014.10.032

146. Bansal T, Alaniz RC, Wood TK, and Jayaraman A (2010). The bacterial signal indole increases epithelial-cell tight-junction resistance and attenuates indicators of inflammation. Proc Natl Acad Sci 107(1):228-33: doi: 10.1073/pnas.0906112107

147. Carpenedo R, Mannaioni G, and Moroni F (2002). Oxindole, a Sedative Tryptophan Metabolite, Accumulates in Blood and Brain of Rats with Acute Hepatic Failure. J Neurochem 70(5):1998-2003. doi: 10.1046/j.1471-4159.1998.70051998.x

148. Bhattacharya SK, Ramnathan M, and Glover V (2000). Intraventricular administration of isatin in rats: antidiuretic, dipsogenic, anorexiant and emetic effects. Biog Amin 16(1):63-71.

149. Satayan KS, Rai A, Jaiswal AK, Acharya SB, and Bhattacharya SK (1995). Isatin, a putative anxiogenic endocoid, induces memory 
dysfunction in rats. Indian J Exp Biol 33(8):576-9. PMID: 8543325

150. Bhattacharya SK, Mitra SK, and Acharya SB (1991). Anxiogenic activity of isatin, a putative biological factor, in rodents. J Psychopharmacol 5(3):202-6. doi: 10.1177/026988119100500304

151. Abel EL (1995). Behavioral effects of isatin on open field activity and immobility in the forced swim test in rats. Physiol Behav 57(3):611-3. doi: 10.1016/0031-9384(94)00365-C

152. Kochanowska-Karamyan AJ, and Hamann MT (2010). Marine indole alkaloids: Potential new drug leads for the control of depression and anxiety. Chem Rev 110(8):4489-97. doi: 10.1021/cr900211p

153. Rothhammer $V$, Mascanfroni ID, Bunse L, Takenaka MC, Kenison JE, Mayo L, Chao CC, Patel B, Yan R, Blain M, Alvarez JI, Kébir $H$, Anandasabapathy N, Izquierdo G, Jung S, Obholzer N, Pochet N, Clish CB, Prinz M, Prat A, Antel J, and Quintana FJ (2016). Type i interferons and microbial metabolites of tryptophan modulate astrocyte activity and central nervous system inflammation via the aryl hydrocarbon receptor. Nat Med 22(6): 586-597. doi: 10.1038/nm.4106

154. Jaglin M, Rhimi M, Philippe C, Pons N, Bruneau A, Goustard B, Daugé $V$, Maguin E, Naudon L, and Rabot $S$ (2018). Indole, a signaling molecule produced by the gut microbiota, negatively impacts emotional behaviors in rats. Front Neurosci 12:216. doi: 10.3389/fnins.2018.00216

155. Lamas B, Richard ML, Leducq V, Pham HP, Michel ML, Da Costa G, Bridonneau C, Jegou S, Hoffmann TW, Natividad JM, Brot L, Taleb S, Couturier-Maillard A, Nion-Larmurier I, Merabtene F, Seksik P, Bourrier A, Cosnes J, Ryffel B, Beaugerie L, Launay JM, Langella P, Xavier RJ, and Sokol H (2016). CARD9 impacts colitis by altering gut microbiota metabolism of tryptophan into aryl hydrocarbon receptor ligands. Nat Med 22(6):598-605. doi: 10.1038/nm.4102

156. Zelante T, lannitti RG, Cunha C, DeLuca A, Giovannini G, Pieraccini G, Zecchi R, D'Angelo C, Massi-Benedetti C, Fallarino F, Carvalho A, Puccetti $P$, and Romani L (2013). Tryptophan catabolites from microbiota engage aryl hydrocarbon receptor and balance mucosal reactivity via interleukin-22. Immunity 39(2):372-85. doi: 10.1016/j.immuni.2013.08.003

157. Venkatesh M, Mukherjee S, Wang H, Li H, Sun K, Benechet AP, Qiu Z, Maher L, Redinbo MR, Phillips RS, Fleet JC, Kortagere S, Mukherjee P, Fasano A, Le Ven J, Nicholson JK, Dumas ME, Khanna KM, and Mani S (2014). Symbiotic bacterial metabolites regulate gastrointestinal barrier function via the xenobiotic sensor PXR and toll-like receptor 4. Immunity 41(2):296-310. doi: 10.1016/j.immuni.2014.06.014

158. Hwang IK, Yoo KY, Li H, Park OK, Lee CH, Choi JH, Jeong YG, Lee YL, Kim YM, Kwon YG, and Won MH (2009). Indole-3-propionic acid attenuates neuronal damage and oxidative stress in the ischemic hippocampus. J Neurosci Res 87(9):2126-37. doi: 10.1002/jnr.22030

159. Chyan YJ, Poeggeler B, Omar RA, Chain DG, Frangione B, Ghiso J, and Pappolla MA (1999). Potent neuroprotective properties against the Alzheimer $\beta$-amyloid by an endogenous melatonin-related indole structure, indole-3-propionic acid. J Biol Chem 274(31):21937-42. doi: 10.1074/jbc.274.31.21937

160. Dou L, Jourde-Chiche N, Faure V, Cerini C, Berland Y, DignatGeorge $F$, and Brunet $P$ (2007). The uremic solute indoxyl sulfate induces oxidative stress in endothelial cells. J Thromb Haemost 5(6):1302-8. doi: 10.1111/j.1538-7836.2007.02540.x

161. Ríos-Covián D, Ruas-Madiedo $P$, Margolles A, Gueimonde $M$, De los Reyes-Gavilán CG, and Salazar N (2016). Intestinal short chain fatty acids and their link with diet and human health. Front Microbiol 7: 185. doi: 10.3389/fmicb.2016.00185

162. Tahara Y, Yamazaki M, Sukigara H, Motohashi H, Sasaki H,
Miyakawa H, Haraguchi A, Ikeda Y, Fukuda S, and Shibata S (2018). Gut Microbiota-Derived Short Chain Fatty Acids Induce Circadian Clock Entrainment in Mouse Peripheral Tissue. Sci Rep 8(1): 1395. doi: 10.1038/s41598-018-19836-7

163. Knudsen GM, Paulson OB, and Hertz MM (1991). Kinetic analysis of the human blood-brain barrier transport of lactate and its influence by hypercapnia. J Cereb Blood Flow Metab 11(4): 581-586. doi: 10.1038/jcbfm.1991.107

164. Walls $A B$, Heimbürger $C M$, Bouman SD, Schousboe $A$, and Waagepetersen HS (2009). Robust glycogen shunt activity in astrocytes: Effects of glutamatergic and adrenergic agents. Neuroscience 158(1): 284-292. doi: 10.1016/j.neuroscience.2008.09.058

165. Barros LF (2013). Metabolic signaling by lactate in the brain. Trends Neurosci 36(7): 396-404. doi: 10.1016/j.tins.2013.04.002

166. Mosienko V, Teschemacher AG, and Kasparov S (2015). Is Llactate a novel signaling molecule in the brain? J Cereb Blood Flow Metab 35(7):1069-1075. doi: 10.1038/jcbfm.2015.77

167. Chen J jun, Zhou C juan, Zheng $P$, Cheng K, Wang $H$ yang, Li J, Zeng $L$, and Xie $P$ (2017). Differential urinary metabolites related with the severity of major depressive disorder. Behav Brain Res 332: 280287. doi: 10.1016/j.bbr.2017.06.012

168. Swann JR, Garcia-Perez I, Braniste V, Wilson ID, Sidaway JE, Nicholson JK, Pettersson S, and Holmes E (2017). Application of1H NMR spectroscopy to the metabolic phenotyping of rodent brain extracts: A metabonomic study of gut microbial influence on host brain metabolism. J Pharm Biomed Anal 143: 141-146. doi: 10.1016/j.jpba.2017.05.040

169. Lauritzen KH, Morland C, Puchades M, Holm-Hansen S, Hagelin EM, Lauritzen F, Attramadal $H$, Storm-Mathisen J, Gjedde A, and Bergersen LH (2014). Lactate receptor sites link neurotransmission, neurovascular coupling, and brain energy metabolism. Cereb Cortex 24(10): 2784-2795. doi: 10.1093/cercor/bht136

170. Shoblock J, Welty N, Chen G, Yun S, Lovenberg T, Liu C, Bonaventure $P$, and Shelton J (2012). Characterizing the Behavioral Phenotype of GPR81 Knockout Mice: Is GPR81 a Novel Target Relevant to Mood Disorders? 67th Annual Scientific Convention and Meeting of the Society-of-Biological-Psychiatry, p. $145 \mathrm{~S}$.

171. Hoque R, Farooq A, Ghani A, Gorelick F, and Mehal WZ (2014). Lactate reduces liver and pancreatic injury in toll-like receptor- and inflammasome-mediated inflammation via gpr81-mediated suppression of innate immunity. Gastroenterology. 146(7): 17631774. doi: 10.1053/j.gastro.2014.03.014

172. Morland $\mathrm{C}$, Lauritzen $\mathrm{KH}$, Puchades $\mathrm{M}$, Holm-Hansen $\mathrm{S}$, Andersson K, Gjedde A, Attramadal H, Storm-Mathisen J, and Bergersen LH (2015). The lactate receptor, G-protein-coupled receptor 81/hydroxycarboxylic acid receptor 1: Expression and action in brain. J Neurosci Res 93(7): 1045-1055. doi: 10.1002/jnr.23593

173. Karnib N, El-Ghandour R, El Hayek L, Nasrallah $P$, Khalifeh M, Barmo N, Jabre V, Ibrahim P, Bilen M, Stephan JS, Holson EB, Ratan RR, and Sleiman SF (2019). Lactate is an antidepressant that mediates resilience to stress by modulating the hippocampal levels and activity of histone deacetylases. Neuropsychopharmacology 44(6):1152-1162. doi: 10.1038/s41386-019-0313-z

174. Carrard A, Elsayed M, Margineanu M, Boury-Jamot B, Fragnière L, Meylan EM, Petit JM, Fiumelli H, Magistretti PJ, and Martin JL (2018). Peripheral administration of lactate produces antidepressant-like effects. Mol Psychiatry 23(2): 392-399. doi: 10.1038/mp.2016.179

175. Suzuki A, Stern SA, Bozdagi O, Huntley GW, Walker RH, Magistretti PJ, and Alberini CM (2011). Astrocyte-neuron lactate transport is required for long-term memory formation. Cell 


\section{4(5):810-23. doi: 10.1016/j.cell.2011.02.018}

176. Petriz BA, Castro AP, Almeida JA, Gomes CPC, Fernandes GR, Kruger RH, Pereira RW, and Franco OL (2014). Exercise induction of gut microbiota modifications in obese, non-obese and hypertensive rats. BMC Genomics 15: 511. doi: 10.1186/1471-2164-15-511

177. Allen JM, Mailing L, Niemiro GM, Moore R, Cook MD, White BA, Holscher HD, and Woods JA (2018). Exercise Alters Gut Microbiota Composition and Function in Lean and Obese Humans. Med Sci Sports Exerc 50(4):747-757. doi: 10.1249/MSS.0000000000001495

178. Russell DW (2003). The Enzymes, Regulation, and Genetics of Bile Acid Synthesis. Annu Rev Biochem 72(1): 137-174. doi: 10.1146/annurev.biochem.72.121801.161712

179. Ferrebee CB, and Dawson PA (2015). Metabolic effects of intestinal absorption and enterohepatic cycling of bile acids. Acta Pharm Sin B 5(2):129-134. doi: 10.1016/j.apsb.2015.01.001

180. Mertens KL, Kalsbeek A, Soeters MR, and Eggink HM (2017). Bile acid signaling pathways from the enterohepatic circulation to the central nervous system. Front Neurosci 11:617. doi: 10.3389/fnins.2017.00617

181. Ding L, Yang L, Wang Z, and Huang W (2015). Bile acid nuclear receptor FXR and digestive system diseases. Acta Pharm Sin B 5(2):135-44. doi: 10.1016/j.apsb.2015.01.004

182. Seok S, Fu T, Choi SE, Li Y, Zhu R, Kumar S, Sun X, Yoon G, Kang Y, Zhong W, Ma J, Kemper B, and Kemper JK (2014). Transcriptional regulation of autophagy by an FXR-CREB axis. Nature 516(729): 108111. doi: 10.1038/nature13949

183. Huang C, Wang J, Hu W, Wang C, Lu X, Tong L, Wu F, and Zhang $W$ (2016). Identification of functional farnesoid $X$ receptors in brain neurons. FEBS Lett 590(18):3233-3242. doi: 10.1002/18733468.12373

184. Chen WG, Zheng JX, Xu X, Hu YM, and Ma YM (2018). Hippocampal FXR plays a role in the pathogenesis of depression: A preliminary study based on lentiviral gene modulation. Psychiatry Res 264: 374-379. doi: 10.1016/j.psychres.2018.04.025

185. Huang $F$, Wang $T$, Lan $Y$, Yang L, Pan W, Zhu Y, Lv B, Wei Y, Shi H, Wu H, Zhang B, Wang J, Duan X, Hu Z, and Wu X (2015). Deletion of mouse FXR gene disturbs multiple neurotransmitter systems and alters neurobehavior. Front Behav Neurosci 9: 70. doi: 10.3389/fnbeh.2015.00070

186. Sinal CJ, Tohkin M, Miyata M, Ward JM, Lambert G, and Gonzalez FJ (2000). Targeted disruption of the nuclear receptor FXR/BAR impairs bile acid and lipid homeostasis. Cell 102(6): 731-744. doi: 10.1016/S0092-8674(00)00062-3

187. Zhang F, Jia Z, Gao P, Kong H, Li X, Lu X, Wu Y, and Xu G (2010). Metabonomics study of urine and plasma in depression and excess fatigue rats by ultra fast liquid chromatography coupled with ion traptime of flight mass spectrometry. Mol Biosyst 6(5): 852. doi: 10.1039/b914751a

188. Yu M, Jia H, Zhou C, Yang Y, Zhao Y, Yang M, and Zou Z (2017). Variations in gut microbiota and fecal metabolic phenotype associated with depression by $16 \mathrm{~S}$ rRNA gene sequencing and LC/MS-based metabolomics. J Pharm Biomed Anal 138: 231-239. doi: 10.1016/j.jpba.2017.02.008

189. Su ZH, Jia HM, Zhang HW, Feng YF, An L, and Zou ZM (2014). Hippocampus and serum metabolomic studies to explore the regulation of Chaihu-Shu-Gan-San on metabolic network disturbances of rats exposed to chronic variable stress. Mol Biosyst 10(3): 549-561. doi: $10.1039 / \mathrm{c} 3 \mathrm{mb} 70377 \mathrm{k}$

190. Quinn M, McMillin M, Galindo C, Frampton G, Pae HY, and DeMorrow $S$ (2014). Bile acids permeabilize the blood brain barrier after bile duct ligation in rats via Rac1-dependent mechanisms. Dig Liver Dis 46(6): 527-534. doi: 10.1016/j.dld.2014.01.159

191. Raimondi F, Santoro P, Barone MV, Pappacoda S, Barretta ML, Nanayakkara M, Apicella C, Capasso L, and Paludetto R (2008). Bile acids modulate tight junction structure and barrier function of Caco-2 monolayers via EGFR activation. Am J Physiol Liver Physiol 294(4): G906-G913. doi: 10.1152/ajpgi.00043.2007

192. Lu X, Yang RR, Zhang JL, Wang P, Gong Y, Hu W feng, Wu Y, Gao $M$ hui, and Huang $C$ (2018). Tauroursodeoxycholic acid produces antidepressant-like effects in a chronic unpredictable stress model of depression via attenuation of neuroinflammation, oxido-nitrosative stress, and endoplasmic reticulum stress. Fundam Clin Pharmacol 32(4): 363-377. doi: 10.1111/fcp.12367

193. Yanguas-Casás N, Barreda-Manso MA, Nieto-Sampedro M, and Romero-Ramírez L (2017). TUDCA: An Agonist of the Bile Acid Receptor GPBAR1/TGR5 With Anti-Inflammatory Effects in Microglial Cells. J Cell Physiol 232(8): 2231-2245. doi: 10.1002/jcp.25742

194. Hylemon PBPB, Zhou H, Pandak WMWM, Ren S, Gil G, and Dent P (2009). Bile acids as regulatory molecules. J Lipid Res 50(8): 1509-20. doi: 10.1194/jlr.R900007-JLR200

195. Moore LB, Goodwin B, Jones SA, Wisely GB, Serabjit-Singh CJ, Willson TM, Collins JL, and Kliewer SA (2000). St. John's wort induces hepatic drug metabolism through activation of the pregnane $X$ receptor. Proc Natl Acad Sci U S A 97(13): 7500-2. doi: 10.1073/pnas.130155097

196. Spedding S (2014). Vitamin D and depression: A systematic review and meta-analysis comparing studies with and without biological flaws. Nutrients 6(4):1501-1518. doi: 10.3390/nu6041501

197. Corbin KD, and Zeisel SH (2012). Choline metabolism provides novel insights into nonalcoholic fatty liver disease and its progression. Curr Opin Gastroenterol 28(2):159-65. doi: 10.1097/MOG.0b013e32834e7b4b

198. Dumas M-E, Barton RH, Toye A, Cloarec O, Blancher C, Rothwell A, Fearnside J, Tatoud R, Blanc V, Lindon JC, Mitchell SC, Holmes E, McCarthy MI, Scott J, Gauguier D, and Nicholson JK (2006). Metabolic profiling reveals a contribution of gut microbiota to fatty liver phenotype in insulin-resistant mice. Proc Natl Acad Sci 103(33): 12511-12516. doi: 10.1073/pnas.0601056103

199. Wang Z, Roberts AB, Buffa JA, Levison BS, Zhu W, Org E, Gu X, Huang $Y$, Zamanian-Daryoush M, Culley MK, Didonato AJ, Fu X, Hazen JE, Krajcik D, Didonato JA, Lusis AJ, and Hazen SL (2015). Non-lethal Inhibition of Gut Microbial Trimethylamine Production for the Treatment of Atherosclerosis. Cell 163(7): 1585-1595. doi: 10.1016/j.cell.2015.11.055

200. Tian JS, Shi BY, Xiang H, Gao S, Qin XM, and Du GH (2013). $1 \mathrm{H}$ NMR-Based Metabonomic Studies on the Anti-Depressant Effect of Genipin in the Chronic Unpredictable Mild Stress Rat Model. PLoS One 8(9): e75721. doi: 10.1371/journal.pone.0075721

201. Romano KA, Martinez-del Campo A, Kasahara K, Chittim CL, Vivas El, Amador-Noguez D, Balskus EP, and Rey FE (2017). Metabolic, Epigenetic, and Transgenerational Effects of Gut Bacterial Choline Consumption. Cell Host Microbe 22(3): 279-290.e7. doi: 10.1016/j.chom.2017.07.021

202. Renshaw PF, Lafer B, Babb SM, Fava M, Stoll AL, Christensen JD, Moore CM, Yurgelun-Todd DA, Bonello CM, Pillay SS, Rothschild AJ, Nierenberg AA, Rosenbaum JF, and Cohen BM (1997). Basal ganglia choline levels in depression and response to fluoxetine treatment: An in vivo proton magnetic resonance spectroscopy study. Biol Psychiatry 41(8): 837-843. doi: 10.1016/S0006-3223(96)00256-9

203. Ende G, Braus DF, Walter S, Weber-Fahr W, and Henn FA (2000). The hippocampus in patients treated with electroconvulsive therapy: 
A proton magnetic resonance spectroscopic imaging study. Arch Gen Psychiatry 57(10): 937-943. doi: 10.1001/archpsyc.57.10.937

204. Tian JS, Xia XT, Wu YF, Zhao L, Xiang H, Du GH, Zhang X, and Qin $X M(2016)$. Discovery, screening and evaluation of a plasma biomarker panel for subjects with psychological suboptimal health state using 1 H-NMR-based metabolomics profiles. Sci Rep 6: 33820. doi: $10.1038 /$ srep33820

205. Charles HC, Lazeyras F, Krishnan KRR, Boyko OB, Payne M, and Moore D (1994). Brain choline in depression: In vivo detection of potential pharmacodynamic effects of antidepressant therapy using hydrogen localized spectroscopy. Prog Neuropsychopharmacol Biol Psychiatry 18(7): 1121-1127. doi: 10.1016/0278-5846(94)90115-5

206. Hamakawa H, Kato T, Murashita J, and Kato N (1998). Quantitative proton magnetic resonance spectroscopy of the basal ganglia in patients with affective disorders. Eur Arch Psychiatry Clin Neurosci 248(1): 53-58. doi: 10.1007/s004060050017

207. MacMaster FP, and Kusumakar V (2006). Choline in pediatric depression. McGill J Med 9(1): 24-27. PMID: 19529805

208. Moore GJ, Stewart CM, Seraji-Bozorgzad N, Paulson LD, Wilds IB, and Rosenberg DR (2002). 314. Brain chemistry in pediatric depression. Biol Psychiatry 47(8): S95. doi: 10.1016/s0006-3223(00)00578-3

209. Steingard RJ, Yurgelun-Todd DA, Hennen J, Moore JEC, Moore CM, Vakili K, Young AD, Katic A, Beardslee WR, and Renshaw PF (2000). Increased orbitofrontal cortex levels of choline in depressed adolescents as detected by in vivo proton magnetic resonance spectroscopy. Biol Psychiatry 48(11): 1053-1061. doi: 10.1016/S00063223(00)00942-2

210. Zheng P, Wang Y, Chen L, Yang D, Meng H, Zhou D, Zhong J, Lei $Y$, Melgiri ND, and Xie $P$ (2013). Identification and validation of urinary metabolite biomarkers for major depressive disorder. Mol Cell Proteomics 12(1): 207-14. doi: 10.1074/mcp.M112.021816

211. Chen J jun, Zhou $C$ juan, Zheng $P$, Cheng $K$, Wang $H$ yang, Li J, Zeng $L$, and Xie $P$ (2017). Differential urinary metabolites related with the severity of major depressive disorder. Behav Brain Res 332: 280287. doi: 10.1016/j.bbr.2017.06.012

212. Mellott TJ, Kowall NW, Lopez-Coviella I, and Blusztajn JK (2007). Prenatal choline deficiency increases choline transporter expression in the septum and hippocampus during postnatal development and in adulthood in rats. Brain Res 1151(1): 1-11. doi: 10.1016/j.brainres.2007.03.004

213. Paternain L, Martisova E, Campión J, Martínez JA, Ramírez MJ, and Milagro $\mathrm{FI}$ (2016). Methyl donor supplementation in rats reverses the deleterious effect of maternal separation on depression-like behaviour. Behav Brain Res 299: 51-58. doi: 10.1016/j.bbr.2015.11.031

214. Di Pierro F, and Settembre R (2015). Preliminary results of a randomized controlled trial carried out with a fixed combination of Sadenosyl-L-methionine and betaine versus amitriptyline in patients with mild depression. Int J Gen Med 8: 73-78. doi: 10.2147/IJGM.S79518

215. Babb SM, Ke Y, Lange N, Kaufman MJ, Renshaw PF, and Cohen BM (2004). Oral choline increases choline metabolites in human brain. Psychiatry Res - Neuroimaging. 130(1): 1-9. doi: 10.1016/S09254927(03)00104-5

216. Mineur YS, and Picciotto MR (2010). Nicotine receptors and depression: Revisiting and revising the cholinergic hypothesis. Trends Pharmacol Sci 31(12):580-586. doi: 10.1016/j.tips.2010.09.004

217. Sawada N, Takanaga H, Matsuo H, Naito M, Tsuruo T, and Sawada $Y$ (1999). Choline uptake by mouse brain capillary endothelial cells in culture. J Pharm Pharmacol 51(7): 847-852. doi: 10.1211/0022357991773050
218. Akbarian-Moghari A, Mohtadi-Nia J, Mofid V, Homayouni-Rad A, Asghari-Jafarabadi M, Niafar M, and Ejtahed HS (2011). Effect of probiotic yogurt containing Lactobacillus acidophilus and Bifidobacterium lactis on lipid profile in individuals with type 2 diabetes mellitus. J Dairy Sci 94(7): 3288-3294. doi: 10.3168/jds.20104128

219. Jung SP, Lee KM, Kang JH, Yun S II, Park HO, Moon Y, and Kim JY (2013). Effect of Lactobacillus gasseri BNR17 on overweight and obese adults: A randomized, double-blind clinical trial. Korean J Fam Med 34(2): 80-89. doi: 10.4082/kjfm.2013.34.2.80

220. Tripolt NJ, Leber B, Triebl A, Köfeler H, Stadlbauer V, and Sourij H (2015). Effect of Lactobacillus casei Shirota supplementation on trimethylamine- $\mathrm{N}$-oxide levels in patients with metabolic syndrome: An open-label, randomized study. Atherosclerosis 242(1): 141-144. doi: 10.1016/j.atherosclerosis.2015.05.005

221. Gu Q, and Li P (2016). Biosynthesis of Vitamins by Probiotic Bacteria. In: Probiotics Prebiotics Hum Nutr Heal. doi: 10.5772/63117

222. Wu D, and Pardridge WM (1999). Blood-brain barrier transport of reduced folic acid. Pharm Res 16(3): 415-419. doi: 10.1023/A:1018829920158

223. Kennedy DO (2016). B vitamins and the brain: Mechanisms, dose and efficacy-A review. Nutrients 8(2):68. doi: 10.3390/nu8020068

224. Miller AL (2008). The methylation, neurotransmitter, and antioxidant connections between folate and depression. Altern Med Rev 13(3):216-226. PMID: 18950248

225. Rossi M, Amaretti A, and Raimondi S (2011). Folate production by probiotic bacteria. Nutrients 3(1): 118-134. doi: 10.3390/nu3010118

226. Brocardo PS, Budni J, Kaster MP, Santos ARS, and Rodrigues ALS (2008). Folic acid administration produces an antidepressant-like effect in mice: Evidence for the involvement of the serotonergic and noradrenergic systems. Neuropharmacology 54(2): 464-473. doi: 10.1016/j. neuropharm.2007.10.016

227. Gao L, Liu X, Yu L, Wu J, Xu M, and Liu Y (2017). Folic acid exerts antidepressant effects by upregulating brain-derived neurotrophic factor and glutamate receptor 1 expression in brain. Neuroreport 28(16): 1078-1084. doi: 10.1097/WNR.0000000000000887

228. Molina-Hernández M, Téllez-Alcántara NP, Olivera-López Jl, and Jaramillo MT (2011). The folic acid combined with $17-\beta$ estradiol produces antidepressant-like actions in ovariectomized rats forced to swim. Prog Neuro-Psychopharmacology Biol Psychiatry 35(1): 60-66. doi: 10.1016/j.pnpbp.2010.08.022

229. Coppen A, Chaudhry S, and Swade C (1986). Folic acid enhances lithium prophylaxis. J Affect Disord 10(1): 9-13. doi: 10.1016/0165 0327(86)90043-1

230. Coppen A, and Bailey J (2000). Enhancement of the antidepressant action of fluoxetine by folic acid: A randomised, placebo controlled trial. J Affect Disord 60(2): 121-130. doi: 10.1016/S0165-0327(00)00153-1

231. Wolf WA, Ziaja E, Arthur RA, Anastasiadis PZ, Levine RA, and Kuhn DM (1991). Effect of Tetrahydrobiopterin on Serotonin Synthesis, Release, and Metabolism in Superfused Hippocampal Slices. J Neurochem 57(4): 1191-1197. doi: 10.1111/j.14714159.1991.tb08279.x

232. Brocardo PS, Budni J, Lobato KR, Santos ARS, and Rodrigues ALS (2009). Evidence for the involvement of the opioid system in the antidepressant-like effect of folic acid in the mouse forced swimming test. Behav Brain Res 200(1): 122-127. doi: 10.1016/j.bbr.2009.01.004

233. Crider KS, Yang TP, Berry RJ, and Bailey LB (2012). Folate and DNA Methylation: A Review of Molecular Mechanisms and the Evidence for 
Folate's Role. Adv Nutr 3(1): 21-38. doi: 10.3945/an.111.000992

234. McCoy CR, Rana S, Stringfellow SA, Day JJ, Wyss JM, Clinton SM, and Kerman IA (2016). Neonatal maternal separation stress elicits lasting DNA methylation changes in the hippocampus of stressreactive Wistar Kyoto rats. Eur J Neurosci 44(10): 2829-2845. doi: 10.1111/ejn.13404

235. Kagan BL, Sultzer DL, Rosenlicht N, and Gerner RH (1990). Oral Sadenosylmethionine in depression: A randomized, double-blind, placebo-controlled trial. Am J Psychiatry 147(5): 591-595. doi: 10.1176/ajp.147.5.591

236. Bottiglieri T, Hyland K, and Reynolds EH (1994). The Clinical Potential of Ademetionine (S-Adenosylmethionine) in Neurological Disorders. Drugs 48(2):137-152. doi: 10.2165/00003495-19944802000002

237. Young SN, and Ghadirian AM (1989). Folic acid and psychopathology. Prog Neuropsychopharmacol Biol Psychiatry 13(6):841-863. doi: 10.1016/0278-5846(89)90037-7

238. Hutto BR (1997). Folate and cobalamin in psychiatric illness. Compr Psychiatry 38(6): 305-314. doi: 10.1016/S0010440X(97)90925-1

239. Roberts E, Carter B, and Young AH (2018). Caveat emptor: Folate in unipolar depressive illness, a systematic review and meta-analysis. J Psychopharmacol 32(4):377-384. doi: 10.1177/0269881118756060

240. Al-Harbi KS (2012). Treatment-resistant depression: Therapeutic trends, challenges, and future directions. Patient Prefer Adherence 6:369-388. doi: 10.2147/ppa.s29716

241. Messaoudi $M$, Lalonde $R$, Violle $N$, Javelot $H$, Desor $D$, Nejdi $A$, Bisson JF, Rougeot C, Pichelin M, Cazaubiel M, and Cazaubiel JM (2011). Assessment of psychotropic-like properties of a probiotic formulation (Lactobacillus helveticus R0052 and Bifidobacterium longum R0175) in rats and human subjects. Br J Nutr 105(5): 755-764. doi: 10.1017/S0007114510004319

242. Winter SE, Winter MG, Xavier MN, Thiennimitr $P$, Poon $V$, Keestra AM, Laughlin RC, Gomez G, Wu J, Lawhon SD, Popova IE, Parikh SJ, Adams LG, Tsolis RM, Stewart VJ, and Bäumler AJ (2013). Host-derived nitrate boosts growth of E. coli in the inflamed gut. Science 339(6120): 708-711. doi: 10.1126/science.1232467

243. Udina $M$, Castellví $P$, Moreno-España J, Navinés R, Valdés $M$, Forns X, Langohr K, Solà R, Vieta E, and Martín-Santos R (2012) Interferon-Induced Depression in Chronic Hepatitis C. J Clin Psychiatry 73(08): 1128-1138. doi: 10.4088/JCP.12r07694

244. McNutt MD, Liu S, Manatunga A, Royster EB, Raison CL, Woolwine BJ, Demetrashvili MF, Miller AH, and Musselman DL (2012). Neurobehavioral effects of interferon- $\alpha$ in patients with hepatitis-C: Symptom dimensions and responsiveness to paroxetine. Neuropsychopharmacology 37(6): 1444-1454. doi: 10.1038/npp.2011.330 